\title{
Ruthenium(III) Based Diimine Complexes; Synthesis, Characterization, PXRD Study and Catalytic Hydrogenation of Cyclohexene
}

Abd El-Motaleb M Ramadan ( $\sim$ Ramadanss@hotmail.com )

Taif University https://orcid.org/0000-0002-7643-1144

Mohamed M. Ibrahim

Taif University

Gaber A. M. Mersal

Zagazig University

Ahmed M. Fathy

New Valley University

Morad M. El-Hendawy

Umm Al-Qura University

Sami A. Al-Harbi

Umm Al-Qura University

Hamed M. Al-Saidi

Kafr El-Sheikh University

\section{Research Article}

Keywords: Synthesis, characterization, diimine, ruthenium(III) complexes, DFT study, hydrogenation

Posted Date: April 7th, 2021

DOI: https://doi.org/10.21203/rs.3.rs-385877/v1

License: (9) This work is licensed under a Creative Commons Attribution 4.0 International License.

Read Full License 


\title{
Ruthenium(III) Based diimine Complexes; Synthesis, Characterization, PXRD study and Catalytic Hydrogenation of Cyclohexene
}

\author{
Mohamed M. Ibrahim ${ }^{\mathrm{a}}$, Gaber A. M. Mersal ${ }^{\mathrm{a}}$, Ahmed M. Fathy ${ }^{\mathrm{b}}$, Morad M. El-Hendawy ${ }^{\mathrm{c}}$, \\ Sami A. Al-Harbi ${ }^{\text {, }}$ Hamed M. Al-Saidi ${ }^{\text {, Abd El-Motaleb M. Ramadan }}{ }^{\mathrm{e} *}$ \\ ${ }^{a}$ Chemistry Department, Faculty of Science, Taif University, P.O. Box 11099, Taif 21944, Saudi \\ Arabia \\ ${ }^{b}$ Chemistry Department, Faculty of Science, Zagazig University, Zagazig Egypt \\ 'Chemistry Department, Faculty of Science, New Valley University, Kharga, Egypt \\ ${ }^{\mathrm{d}}$ Chemistry Department of, University College in Al-Jamoum, Umm Al-Qura University, Makkah, \\ Saudi Arabia \\ ${ }^{\mathrm{e}}$ Chemistry Department, Faculty of Science, Kafr El-Sheikh University, Kafr El-Sheikh, Egypt
}

\section{Abstract}

This study deals with preparation and characterization of a group of $\mathrm{Ru}^{\mathrm{III}}$-chelates contains tetradentate diimine ligands. These quadridentate ligands are derived from 2$\mathrm{OH}-1$-naphthaldehyde and a number of aliphatic diamines where the number of methylene groups between the two azomethine nitrogen donors varied from two to six are the components of quadridentate ligands. The pure isolated compounds were subjected to several physicochemical investigations to assign their structures. Spectral and magnetic measurements suggested a distorted octahedral arrangement of the six coordinate diimine ruthenium(III) complexes. The structural optimization for one of the current $\mathrm{Ru}^{\mathrm{III}}$ complexes was determined based on the processing of powder X-ray diffraction (PXRD) data by the computer program Expo 2014 PXRD. As well DFT calculations were applied to optimize the geometry in the case of complexes 1. The newly synthesized ruthenium(III) diimines were tested as catalysts for hydrogenation of cyclohexene. The effect of the catalyst structure and the type of catalysis as well as the nature and amount of the solvent used on the catalytic performance of the current catalysts were studied. Catalytic experiments reported that the ongoing ruthenium(III) complexes are promising precatalysts that have successfully catalyzed hydrogenation of cyclohexene by hydrogen gas under moderate process conditions. The results obtained allowed to establish a mechanism for the studied catalytic hydrogenation reactions.

Keywords: Synthesis, characterization, diimine, ruthenium(III) complexes, DFT study, hydrogenation

*Corresponding author: Ramadanss@ @otmail.com

33516 Kafr El-Sheikh, Egypt; Tel: 00201273604106 ; Fax: 0020473215175 


\section{Introduction}

Catalytic hydrogenation of olefins by molecular hydrogen plays a central role in many industries, such as pharmaceuticals, petrochemical, food, specialty chemicals, commodity chemicals, and agrochemicals [1a-e]. The literature includes numerous studies related to the catalytic hydrogenation of simple olefins by means of transition metal complexes $[2,4]$. The metal complexes showed a distinction in catalytic performance over the metal itself in the hydrogenation processes in terms of higher activity and work under milder conditions [2]. In this respect, a wide range of metal complexes containing $\mathrm{d}^{8}$-metals are widely used to catalyze the hydrogenation of the unsaturated hydrocarbons by $\mathrm{H}_{2}$ [3]. In the same context, 1961 saw the first use of ruthenium complexes in homogeneous catalysis processes to activate $\mathrm{H}_{2}$ [3f].

Catalytic processes in homogeneous systems are simpler from the chemical and kinetic point of view than the heterogeneous catalytic systems. Ruthenium complex, $\left[\mathrm{RuCl}_{2}\left(\mathrm{PPh}_{3}\right)_{3}\right]$, is most commonly used for $\mathrm{H}_{2}$ activation processes by the heterolytic splitting mechanism. The heterolytic splitting of molecular hydrogen to produce a metal monohydride and proton is well known for many catalytic hydrogenation processes of unsaturated hydrocarbons, especially in polar solvents [5]. Presently, many ruthenium complexes with distinct catalytic activity are present in hydrogenation processes for unsaturated bonds of olefins [6]. In particular, monohydride ruthenium-complexes were reported as catalysts with high activity and selectivity towards terminal alkenes [7].

The metal complexes of Schiff's bases play major roles in the progression of metal complexes chemistry. Among these metal complexes worth mentioning in this regard and which has been used as a catalyst in hydrogenation of simple alkene by $\mathrm{H}_{2}$ is the palladium(II) complex containing $\mathrm{N}_{2} \mathrm{O}_{2}$ donor sites of the tetradentate Schiff base ligand (salen) [8]. Within our knowledge the use of ruthenium(III) Schiff base complexes as catalysts for hydrogenation of simple alkenes by $\mathrm{H}_{2}$ is not yet known. Only one investigation could be found reporting the reductive carbonylation of nitrobenzene to phenyl urethane catalyzed by ruthenium(III) Schiff bases of the general formula [Ru $\left.{ }^{\mathrm{III}} \mathrm{LCl}\right]$ or $\left[\mathrm{Ru}^{\mathrm{III}} \mathrm{LCl}_{2}\right]$, where $\mathrm{L}$ is Schiff base with $\mathrm{N}_{2} \mathrm{O}_{2}, \mathrm{~N}_{4}$ and NS donor groups [9]. Among the complexes tested $\left(\mathrm{Ru}-\mathrm{SolphCl}_{2}\right)$ showed the highest catalytic activity but kinetic studies and mechanism elucidations were not reported. 
The aim of the current study is to synthesis and characterize a new series of ruthenium(III) complexes with tetradentate Schiff bases containing $\mathrm{N}_{2} \mathrm{O}_{2}$ donors for catalytic hydrogenation of the simple olefin, cyclohexene, by $\mathrm{H}_{2}$.

\section{Experimental}

\subsection{Chemicals and Materials:}

All the materials used in the present study are of a high degree of purity as they were purchased from reliable sources. The current diimine ligands were prepared according to the method reported elsewhere [10].

\subsection{Preparation of diimine ruthenium(III) complexes 1 - 4}

An ethanol solution $(50 \mathrm{~mL}$ ) containing $0.2 \mathrm{~mol}$ of ligand diamine was heated for 30 minutes and followed by adding an equivalent amount of ruthenium salt $\left(\mathrm{RuCl}_{3} 3 \mathrm{H}_{2} \mathrm{O}\right)$ dissolved in $50 \mathrm{ml}$ of absolute ethanol. After that, the precipitate formed was filtered, washed with alcohol, ether, and then placed in a desiccator over $\mathrm{P}_{2} \mathrm{O}_{5}$ for a week. In most cases addition of ether was desirable to complete precipitation of the metal chelate. Significant purity of metal chelates was achieved through further washing with the Soxhlet process with ethanol as the solvent. The composition of the pure isolated ruthenium(III) complexes was primarily established by elemental analysis which is recorded in Table 1.

2.3. Physical measurements, the catalytic hydrogenation process that includes the hydrogenation apparatus, experiments, the analytical process and computational details are given in the Supplementary Information S1.

\section{Results and Discussion}

\subsection{Characterization of $R u^{I I I}$-based diimines}

The present study aims to prepare and characterize a group of $\mathrm{Ru}^{\mathrm{III}}$ - based complexes containing diimine ligands derived from 2-OH-1-naphthaldehyde and a number of aliphatic diamines with carbon chain in which the number of carbon atoms ranges from two to six. The reaction of the hydrated ruthenium trichloride salt $\left(\mathrm{RuCl}_{3}\right.$ $3 \mathrm{H}_{2} \mathrm{O}$ ) in ethanolic solution with these Schiff bases gave a family of ruthenium(III) chelates which was subjected to several physicochemical investigations to assign their 
structures. In this respect, the results of elemental analysis in Table 1 demonstrated that the molar ratio of the newly prepared ruthenium(III) diimine complexes is 1:1. The molar conductance measurements in DMF at room temperature as shown in Table 1 indicate their nonelectrolytic behavior [12]. The full structural characterization of these ruthenium(III) Schiff base complexes was completed via comprehensive spectroscopic studies. The analytical data and the incoming spectral results demonstrate that the present Schiff bases behave as quadridentate dibasic ligands providing the chromophore $\mathrm{N}_{2} \mathrm{O}_{2}$ to coordinate with ruthenium(III) ion.

Table 1: Molecular formulae, physical prosperities, and analytical data of ruthenium(III) diimines 1-4

\begin{tabular}{ccccccc}
\hline Complex & Color & Solubility & \multicolumn{4}{c}{ Found (Calcd.) } \\
& & & \% C & $\% \mathbf{H}$ & $\% \mathbf{N}$ & $\% \mathbf{M}$ \\
\hline 1. $\left[\mathrm{RuL}^{1} \mathrm{Cl} \mathrm{H} \mathrm{H}_{2} \mathrm{O}\right]$ & Brown & DMF & 54.93 & 3.91 & 5.93 & 19.02 \\
& & & $(55.11)$ & $(4.20)$ & $(5.36)$ & $(19.34)$ \\
2. $\left[\mathrm{RuL}^{2} \mathrm{Cl} \mathrm{H} \mathrm{H}_{2} \mathrm{O}\right]$ & Dark blue & DMF & 56.93 & 4.40 & 5.10 & 18.62 \\
& & & $(56.87)$ & $(4.37)$ & $(5.12)$ & $(18.42)$ \\
3. $\left[\mathrm{RuL}^{3} \mathrm{Cl} \mathrm{H} \mathrm{H}_{2} \mathrm{O}\right]$ & Dark blue & DMF & 57.46 & 5.19 & 4.29 & 17.87 \\
& & & $(57.59)$ & $(4.62)$ & $(4.98)$ & $(17.96)$ \\
4. $\left[\mathrm{RuL}^{4} \mathrm{Cl} \mathrm{H} \mathrm{H}_{2} \mathrm{O}\right]$ & Dark blue & DMF & 58.17 & 5.25 & 4.58 & 17.34 \\
& & & $(58.27)$ & $(4.85)$ & $(4.85)$ & $(17.52)$ \\
\hline
\end{tabular}

\subsection{Thermal analysis (TGA and DTA)}

Thermometry (TGA and DTA) is an important experimental scientific technique in determining the accurate molecular formulae of the hydrated metal complexes. Determination of the thermal stability of metal complexes is also an important factor, particularly when these metal complexes participate in catalytic applications under variable thermal conditions. Therefore, thermal analysis (TGA and DTA) was performed for the ruthenium(III) complexes under study. All thermal measurements were performed in an inert atmosphere of $\mathrm{N}_{2}$ at a temperature range of 50 to $1000{ }^{\circ} \mathrm{C}$ that begins with room temperature and ends when the weight loss constant has been reached as shown in the supplementary materials S2-S5. The corresponding thermal data such as the mass loss, temperature ranges and assigning the chemical compositions of both the thermally 
lost portion and the residual, as well as differential thermal features during the successive pyrolysis stages are given in Table 2.

As is evident from the thermograms curves of the existing ruthenium(III) complexes that the pyrolysis patterns are almost identical. For all complexes the complete pyrolysis proceeds in three successive stages. In the initial pyrolysis stage, within the temperature range of $70-270{ }^{\circ} \mathrm{C}$, the axial complexing ligands, which include the coordinated water molecule, as well as the chloride ion, are volatilized. In the second phase of pyrolysis, partial loss is shown in the organic content of the coordinated Schiff base ligand that leading to formation of an intermediate. In the final stage, the remaining organic part is volatilized, leaving behind the metal content of the metal complex molecule in the form of a metal oxide $\left(\mathrm{RuO}_{2}\right)$. In all the pyrolysis stages, both the experimental and theoretical values of the percentage of weight loss are in a well agreement.

The estimated metal content values from the remaining metal oxide correspond to those estimated by the analytical methods, confirming the validity of the proposed molecular formulae for these ruthenium(III) diimine complexes.

Differential thermal analysis (DTA) curves show that each stage of weight loss is accompanied by an exothermic peak at a definite temperature value that given in Table 2 . In this respect, except in the case of complex 4, no endothermic peaks were observed, indicating that the current ruthenium(III) complexes are not subject to melting or suffer from any changes in the network prior to decomposition. This finding is in an agreement with the fact that the existing ruthenium(III) chelates decompose without melting. 
Table 2: TGA and DTA of ruthenium(III) diimine s 1-4

\begin{tabular}{|c|c|c|c|c|}
\hline Metal chelate & $\mathbf{T}^{\circ} \mathbf{C}$ & $\begin{array}{l}\text { Peaks of } \\
\text { DTA }\left({ }^{\circ} \mathbf{C}\right)\end{array}$ & $\begin{array}{l}\text { \% Lost weight } \\
\text { F. (Cal.) }\end{array}$ & $\begin{array}{l}\text { Fragments } \\
\text { formed }\end{array}$ \\
\hline 1. $\left[\mathrm{RuL}^{1} \mathrm{ClH}_{2} \mathrm{O}\right]$ & $\begin{array}{c}70-200 \\
200-305 \\
305-415\end{array}$ & $\begin{array}{c}- \\
\text { Exo }(255) \\
\text { Exo }(350)\end{array}$ & $\begin{array}{l}10.33(10.27) \\
21.34(22.18) \\
43.28(43.05)\end{array}$ & $\begin{array}{l}\mathrm{RuL} \\
\mathrm{RuL}_{0.65} \\
\mathrm{RuO}_{2}\end{array}$ \\
\hline 2. $\left[\mathrm{RuL}^{2} \mathrm{ClH}_{2} \mathrm{O}\right]$ & $\begin{array}{c}60-270 \\
270-465 \\
465-640\end{array}$ & $\begin{array}{l}\text { Exo }(340) \\
\text { Exo }(455) \\
\text { Exo }(580)\end{array}$ & $\begin{array}{c}8.90(9.19) \\
25.21(25.82) \\
41.36(41.93)\end{array}$ & $\begin{array}{l}\mathrm{RuL} \\
\mathrm{RuL}_{0.62} \\
\mathrm{RuO}_{2}\end{array}$ \\
\hline 3. $\left[\mathrm{RuL}^{3} \mathrm{ClH}_{2} \mathrm{O}\right]$ & $\begin{array}{l}190-210 \\
210-380 \\
380-590\end{array}$ & $\begin{array}{l}\text { Exo }(205) \\
\text { Exo }(300) \\
\text { Exo }(330) \\
\text { Exo }(450)\end{array}$ & $\begin{array}{c}8.50(8.96) \\
40.85(41.23) \\
27.11(27.51)\end{array}$ & $\begin{array}{l}\mathrm{RuL} \\
\mathrm{RuL}_{0.6} \\
\mathrm{RuO}_{2}\end{array}$ \\
\hline 4. $\left[\mathrm{RuL}^{4} \mathrm{ClH}_{2} \mathrm{O}\right]$ & $\begin{array}{l}150-210 \\
210-450 \\
450-650\end{array}$ & $\begin{array}{l}\text { Endo (210) } \\
\text { Exo }(420) \\
\text { Exo }(485)\end{array}$ & $\begin{array}{c}8.45(8.76) \\
30.75(31.24) \\
37.96(38.19)\end{array}$ & $\begin{array}{l}\mathrm{RuL} \\
\mathrm{RuL}_{0.45} \\
\mathrm{RuO}_{2}\end{array}$ \\
\hline
\end{tabular}

\subsection{Infra red spectra}

To illustrate the bonding pattern of the present Schiff bases with the ruthenium (III) ion, the infrared spectra were measured as $\mathrm{KBr}$ disks of both the Schiff base bonds and their corresponding metal chelates. Based on the data obtained from the charts in S6-S13 the spectral assignments of the diimines along with the ruthenium (III) chelate were recorded in Table 3. Observed band shifts can be correlated to changes in the ligand system by coordination and thus give information about the bonding and arrangement in the metal complexes. The spectral features shown in S6-S13 and the frequency data in Table 3 demonstrate that the coordination pattern of Schiff bases with ruthenium(III) center is fairly identical for all metal chelates. The spectra of the complexes reveal the disappearance of the characteristic OH-bands of the ligands due to the destruction of the intermolecular hydrogen bond as a result of the coordination of phenolic oxygen to ruthenium(III) ion [13].

The evanescence of the distinctive peaks to $\mathrm{OH}$ group from the spectra of the ruthenium(III) chelates is consistent with those observed for the palladium(II) and nickel(II) complexes with the same current diimine ligands [2f, 4]. The remarkable shift for the $v(\mathrm{C}-\mathrm{O})$ band at $1415-1450 \mathrm{~cm}^{-1}$ to higher wavenumbers at $1450-1500 \mathrm{~cm}^{-1}$ in 
the spectra of the complexes indicates the bonding of the phenolic oxygen to ruthenium(III) center [14]. In the same regard, the characteristic band of the Schiff base linkage is shifted to higher wavenumbers $\left(1620-1680 \mathrm{~cm}^{-1}\right)$ as shown in table 3 due to bonding of the imine nitrogen to $\mathrm{Ru}^{\mathrm{III}}$-center [14]. The bonding of ruthenium(III) ion to the current ligands through the nitrogen and oxygen is supported by the emergence of new peaks at $490-570$ and $380-450 \mathrm{~cm}^{-1}$ attributable to the $v(\mathrm{M}-\mathrm{N})$ and $v(\mathrm{M}-\mathrm{O})$ respectively [14].

The results of elemental and thermogravimetric analysis showed, that the present Schiff base ligands behave as a dibasic acid which is then bound with ruthenium(III) ion as dianionic tetradentate ligands [13,15]. Since ruthenium(III) ion attains the coordination number six, the remaining coordination sites would be occupied by water molecule and the chloride ion. The broad band appearing at $3400-3450 \mathrm{~cm}^{-1}$ range (Table 3) is an indication of the existence of $\mathrm{H}_{2} \mathrm{O}$ in the metal chelate molecule. The present $\mathrm{TG}$ measurements indicated that the present ruthenium(III) complexes have constant weight till $150{ }^{\circ} \mathrm{C}$ at which they begin to decompose. This fact excluded the surface nature of the water content and supports that the water molecule is coordinated to ruthenium(III) ion.

This fact rule out the superficial nature of the water content and supports the coordination bonding of $\mathrm{H}_{2} \mathrm{O}$ to the ruthenium (III) ion. Further emphasis on the coordination bonding of the water content of the current ruthenium(III) complexes comes from bending vibration patterns observed at 900-930, 790-800 and 660-675 $\mathrm{cm}^{-1}$ which are characteristic of wagging, twisting and rocking absorptions [15]. Participation of chloro ligand in the coordination chromophore around ruthenium(III) ion is inferred from the new band appeared in the spectra of the metal complexes at wavenumber range of 300 $380 \mathrm{~cm}^{-1}$ assignable to $v(\mathrm{M}-\mathrm{Cl})[14]$.

The composition of the current ruthenium(III) imine complexes appears to depend mainly on the number of carbon atoms of the alkyl bridge between the two azomethine groups of the diimine molecule. For $\mathrm{L}^{1}$ its ruthenium(III) complexes is a monomeric in nature as evidenced from its magnetic moment value because the resulting chelate ring is five membered as illustrated in Scheme I. Concerning ruthenium(III) complexes of $\mathrm{L}^{2}, \mathrm{~L}^{3}$ and $\mathrm{L}^{4}$ that contain more than three methylene groups in the bridge between two Schiff base linkages a dimeric or polymeric structure is formed (scheme I) [13]. This is to be expected because the resulting 
chelating ring will be somewhat unstable because it is larger than six membered and therefore the $\mathrm{N}_{2} \mathrm{O}_{2}$ donors cannot be given by a single diimine molecule.

Based on analytical data, measurements of both TG and molar conductance in addition to spectral investigations, the existing ruthenium(III) chelates can be formulated as shown in Scheme I.

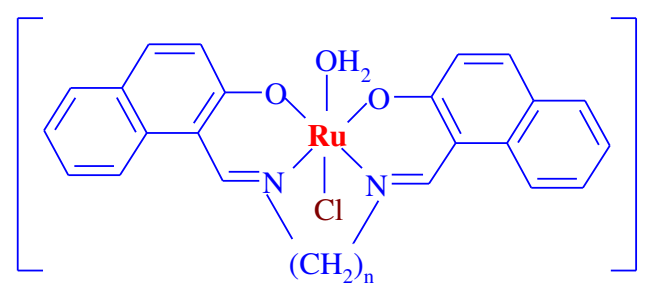

$\left[\mathrm{RuL}^{1} \mathrm{Cl} \mathrm{H} \mathrm{H}_{2} \mathrm{O}\right], \mathrm{n}=2$

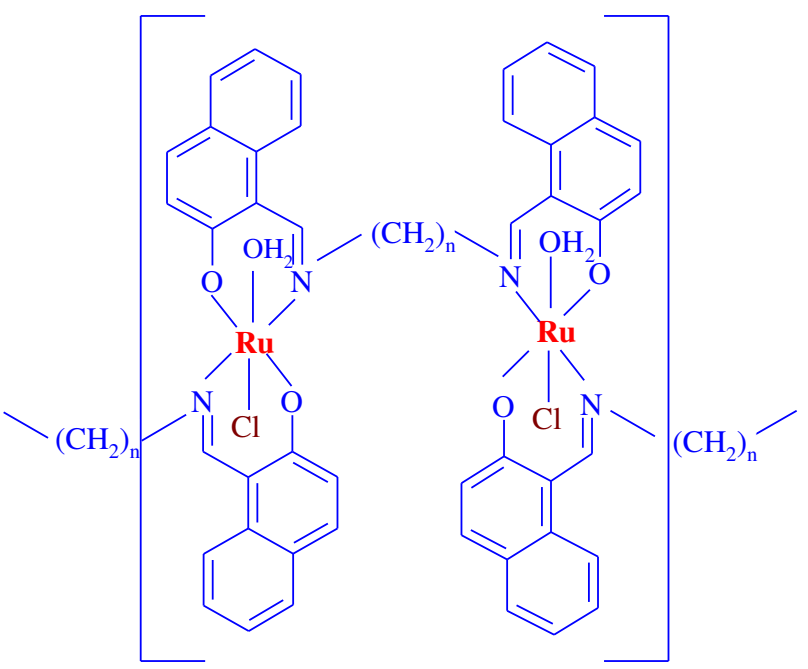

Polymer

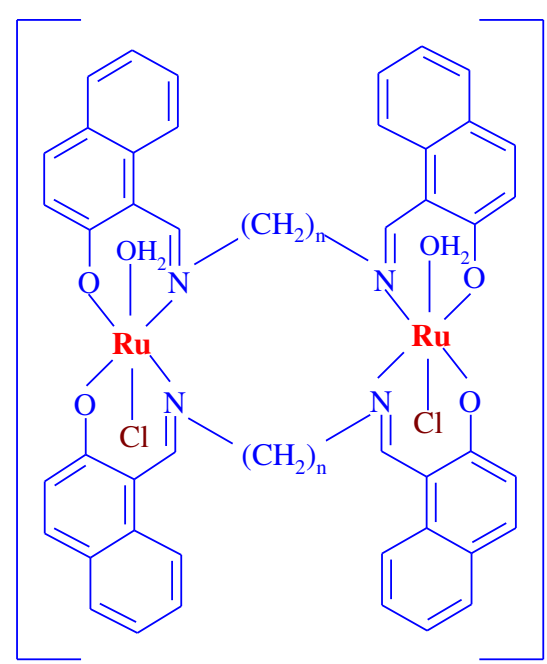

Dimer

For $\mathrm{n}=4,5$ and 6 the resulting ruthenium(III) complexes 2, 3 and 4 are dimeric or polymeric

Scheme I: Structures of ruthenium(III)-based diimine complexes 
Table 3: FTIR spectra $\left(\mathrm{cm}^{-1}\right)$ of diimines and $\mathrm{Ru}^{\mathrm{III}}$-based chelates 1-4

\begin{tabular}{cccccccc}
\hline Compound* & $v(\mathrm{OH})$ & $v(\mathrm{C}=\mathrm{N})$ & $\delta(\mathrm{OH})$ & $v(\mathrm{C}-\mathrm{O})$ & $v(\mathrm{M}-\mathrm{N})$ & $v(\mathrm{M}-\mathrm{O})$ & $v(\mathrm{M}-\mathrm{Cl})$ \\
\hline $1 . \mathrm{RuL}^{1}$ & $3445^{* *}$ & 1620 & - & 1450 & 490 & 380 & 300 \\
$\mathrm{~L}^{1}$ & 3440 & 1616 & 1358 & 1415 & - & - & - \\
2. $\mathrm{RuL}^{2}$ & $3450^{* *}$ & 1680 & - & 1500 & 550 & 450 & 315 \\
$\mathrm{~L}^{2}$ & 3420 & 1620 & 1360 & 1420 & - & - & - \\
3. $\mathrm{RuL}^{3}$ & $3430 * *$ & 1625 & - & 1480 & 500 & 405 & 380 \\
$\mathrm{~L}^{3}$ & 3410 & 1614 & 1373 & 1435 & - & - & - \\
$4 . \mathrm{RuL}^{4}$ & $3430 * *$ & 1650 & - & 1460 & 570 & 420 & 300 \\
$\mathrm{~L}^{4}$ & 3420 & 1614 & 1370 & 1450 & - & - & - \\
\hline
\end{tabular}

*Complex details are as listed in Table $1 ; * *$ the characteristic stretching of the coordinated water $v\left(\mathrm{H}_{2} \mathrm{O}\right)$

\subsection{Electronic absorption spectra}

In the absence of suitable crystals for the structural analysis of metal complexes, spectroscopic techniques and magnetic investigations are an alternative to determine the geometry of metal complex. Accordingly, the UV-Vis spectra of the current ruthenium(III) chelates were recorded as $\mathrm{KBr}$ discs. The spectra recorded for all complexes are approximately the same, indicating that their stereochemistry is identical and presented in S14 while the relevant energy values are explained and listed in Table 4.

Table 4 displays that the strong bands with high frequency values are assignable to charge transfer of the type $\pi \rightarrow t_{2 \mathrm{~g}}\left(\pi^{*}\right)$ transition where $\pi$ is the HOMO orbital of the donor atoms and $\pi^{*}$ is the LUMO orbital, namely the incomplete orbital of the metal ion, $t_{2 \mathrm{~g}}[16]$.

In the absence of any crystal field, metal complexes with $\mathrm{d}^{5}-$ configuration have ${ }^{6} \mathrm{~S}$ ground state term symbol. For the hexa-coordinated $\mathrm{d}^{5}$-metal complexes the ground state becomes ${ }^{6} \mathrm{~A}_{1 \mathrm{~g}}$ and ${ }^{2} \mathrm{~T}_{2 \mathrm{~g}}$ in both the weak and strong ligand field respectively. Ruthenium(III) ion belongs to $d^{5}$ system where ${ }^{2} \mathrm{~T}_{2 \mathrm{~g}}$ is the ground state for the hexacoordinated $\mathrm{d}^{5}$-metal complexes in the low-spin state of the octahedral symmetry. The corresponding electronic configuration is $t^{5} 2 \mathrm{~g}$ and the first excited doublet levels in the power-up arrangement are ${ }^{2} \mathrm{~A}_{2 \mathrm{~g}}$ and ${ }^{2} \mathrm{~T}_{2 \mathrm{~g}}$ respectively [17]. In the $\mathrm{d}^{5}$ system and especially for ruthenium(III) ion in an octahedral geometry the likely spin-allowed ligand field 
transitions are: ${ }^{2} \mathrm{~T}_{2 \mathrm{~g}} \rightarrow{ }^{4} \mathrm{~T}_{1 \mathrm{~g}},{ }^{2} \mathrm{~T}_{2 \mathrm{~g}} \rightarrow{ }^{4} \mathrm{~T}_{2 \mathrm{~g}}$ and ${ }^{2} \mathrm{~T}_{2 \mathrm{~g}} \rightarrow{ }^{2} \mathrm{~A}_{2 \mathrm{~g}}$, corresponding to $v_{1}, v_{2}$ and $v_{3}$, respectively [28]. The spectra of the current ruthenium(III) chelates (S14) exhibit three bands related to the expected d-d spin allowed transitions of the six coordinate $\mathrm{d}^{5}$ - system in an octahedral stereochemistry of low spin ruthenium(III) complexes [17]. These bands appear in the low frequency zones at wavenumber values of 13333 - 13513, 14492 14705 and $18691-19047 \mathrm{~cm}^{-1}$ which are assigned to $v_{1}, v_{2}$ and $v_{3}$, respectively [18]. An analysis of these spectral data allows us to compute the ligand field stabilization energy 10Dq, interelectronic Racah repulsion $B$ and Nephelauxetic ratio $\beta$. 10Dq was determined from the energy difference between the ground state ${ }^{2} \mathrm{~T}_{2 \mathrm{~g}}$ and the excited state ${ }^{2} \mathrm{~A}_{2 \mathrm{~g}}$ based on the relation: ${ }^{2} \mathrm{~T}_{2 \mathrm{~g}} \rightarrow{ }^{2} \mathrm{~A}_{2 \mathrm{~g}}=10 \mathrm{Dq}-3 F_{2}-20 F_{4}$, with $F_{2}=10 F_{4}=1000 \mathrm{~cm}^{-1}$ [18]. In the same regard the parameters $B$ and $C$ were computed from the relations [19]:

$$
\begin{gathered}
{ }^{2} \mathrm{~T}_{2 \mathrm{~g}} \rightarrow{ }^{4} \mathrm{~T}_{1 \mathrm{~g}}\left(\mathrm{v}_{1}\right)=10 \mathrm{Dq}-5 B-4 C \\
{ }^{2} \mathrm{~T}_{2 \mathrm{~g}} \rightarrow{ }^{4} \mathrm{~T}_{2 \mathrm{~g}}\left(\mathrm{v}_{2}\right)=10 \mathrm{Dq}+3 B-4 C \\
{ }^{2} \mathrm{~T}_{2 \mathrm{~g}} \rightarrow{ }^{2} \mathrm{~A}_{2 \mathrm{~g}},{ }^{2} \mathrm{~T}_{1 \mathrm{~g}}\left(\mathrm{v}_{3}\right)=10 \mathrm{Dq}-2 B-C
\end{gathered}
$$

The data in Table 4 show that the values of $B\left(144.87-160.37 \mathrm{~cm}^{-1}\right)$ are less than the corresponding free ion $B_{o}$ value $\left(630 \mathrm{~cm}^{-1}\right)$. The overlap of the orbits of both the ligand and the metal and the penetration of the free lone pairs of ligand to the $d$ orbits of the metal ion leads to blocking or weakening the effect of the positive charge on the metal core, which is reflected in the observed decrease in the value of the electron repulsion [17]. This is reflected in the observed decrease in the value of electron repulsion which in turn causes the electron cloud to expand in d orbitals and consequently the interelectronic repulsion decreases. It is understood that as the valence state of a metal ion increases, its volume decreases and the value of $B_{0}$ increases. However, this marked decrease in $B$ compared to $B_{0}$ indicates the predominance of covalent bonding in the ruthenium(III) complex molecule and thus leads to an increase in values of the ligand field stabilization energy (10Dq). This increase in the values of $10 \mathrm{Dq}$ is generally related to a significant electron delocalization [20]. 
Table 4: UV-Vis spectral data $\left(\mathrm{cm}^{-1}\right)$ of ruthenium(III) diimines 1-4

\begin{tabular}{ccccc}
\hline Complex & ${ }^{2} \mathrm{~T}_{2 \mathrm{~g}} \rightarrow{ }^{4} \mathrm{~T}_{1 \mathrm{~g}}\left(\mathrm{v}_{1}\right)$ & ${ }^{2} \mathrm{~T}_{2 \mathrm{~g}} \rightarrow{ }^{4} \mathrm{~T}_{2 \mathrm{~g}}\left(\mathrm{v}_{2}\right)$ & ${ }^{2} \mathrm{~T}_{2 \mathrm{~g}} \rightarrow{ }^{2} \mathrm{~A}_{2 \mathrm{~g}},{ }^{2} \mathrm{~T}_{1 \mathrm{~g}}\left(\mathrm{v}_{3}\right)$ & $\pi \rightarrow t_{2 \mathrm{~g}}\left(\pi^{*}\right)$ \\
\hline 1. $\left[\mathrm{RuL}{ }^{1} \mathrm{ClH} \mathrm{H}_{2} \mathrm{O}\right]$ & 13333 & 14492 & 18867 & 25000,28169 \\
2. $\left[\mathrm{RuL}^{2} \mathrm{ClH}_{2} \mathrm{O}\right]$ & 13513 & 14705 & 19047 & 25641,32258 \\
3. $\left[\mathrm{RuL}^{3} \mathrm{ClH}_{2} \mathrm{O}\right]$ & 13513 & 14705 & 19047 & 25316,32786 \\
4. $\left[\mathrm{RuL}^{4} \mathrm{ClH}_{2} \mathrm{O}\right]$ & 13422 & 14705 & 18691 & 24691,28169 \\
\hline
\end{tabular}

Table 5: Ligand filed parameters $\left(\mathrm{cm}^{-1}\right)$ and magnetic moments (BM) of Ru(III) diimine complexes 1-4

\begin{tabular}{ccccccc}
\hline Complex & $10 \mathrm{Dq}$ & $C$ & $B$ & $\beta$ & $v_{2 / N_{1}}$ & $\mu_{\text {eff }}$ \\
\hline 1. $\left[\mathrm{RuL}^{1} \mathrm{ClH} \mathrm{H}_{2} \mathrm{O}\right]$ & 23867 & 4710 & 144.87 & 0.22 & 1.089 & 2.12 \\
2. $\left[\mathrm{RuL}^{2} \mathrm{ClH}_{2} \mathrm{O}\right]$ & 24047 & 4702 & 149.00 & 0.23 & 1.088 & 1.66 \\
3. $\left[\mathrm{RuL}^{3} \mathrm{ClH}_{2} \mathrm{O}\right]$ & 24047 & 4702 & 149.00 & 0.23 & 1.088 & 1.64 \\
4. $\left[\mathrm{RuL}^{4} \mathrm{ClH}_{2} \mathrm{O}\right]$ & 23691 & 4679 & 160.37 & 0.25 & 1.095 & 1.65 \\
\hline
\end{tabular}

Magnetic susceptibility measurements at $22{ }^{\circ} \mathrm{C}$ of the current ruthenium(III) diimines (Table 5) demonstrate the low spin state of the $\mathrm{d}^{5}$ ruthenium(III) ion. The data in Table 5

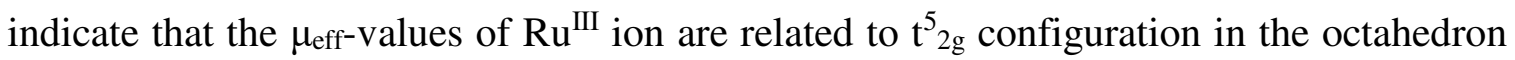

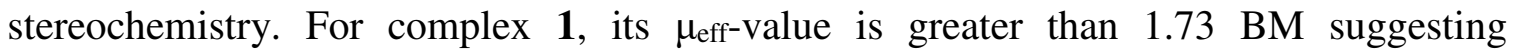
appreciable spin - orbit coupling arising from incomplete quenching of the orbital contribution to the magnetic moment [21]. On the other hand, for complexes $\mathbf{2}, \mathbf{3}$ and $\mathbf{4}$ the values of $\mu_{\text {eff }}$ are lower than the spin only value. This may be an indication of spin spin interactions between the low spin neighboring $\mathrm{Ru}^{\mathrm{III}}$ centers in the dimeric or polymeric structures. As well this observed decrease in the magnetic moments could also arise from an extensive electron delocalization or lowering in the symmetry of ligand fields [22]. In the same regard, for metal complexes of $4 d$ and $5 d$ metals their room temperature magnetic moments are often found below the spin - only values and this behavior could be ascribed to high spin - orbit coupling constants. In this respect, the paramagnetism that can be expected from the unpaired electrons alone is reduced because the spin orbit coupling aligns the vectors $\mathrm{L}$ and $\mathrm{S}$ in opposite directions [23]. 
However, the magnetic moment values (Table 5) and the electronic absorption spectral properties of the current ruthenium(III) Schiff bases complexes are characteristic of the octahedral structure and are comparable with other ruthenium(III) complexes [24].

\subsection{Structure solution by PXRD and DTF study}

Due to the practical difficulty in obtaining a single crystal suitable for the present $\mathrm{Ru}^{\mathrm{III}}$-based complexes, we could not perform a good structural analysis. However, the structural solution for metal complexes based on the processing of powder X-ray diffraction (PXRD) data by a structure solution computer program such as Expo 2014 is now common and accepted as an alternative of single crystal structural analysis technique [4].

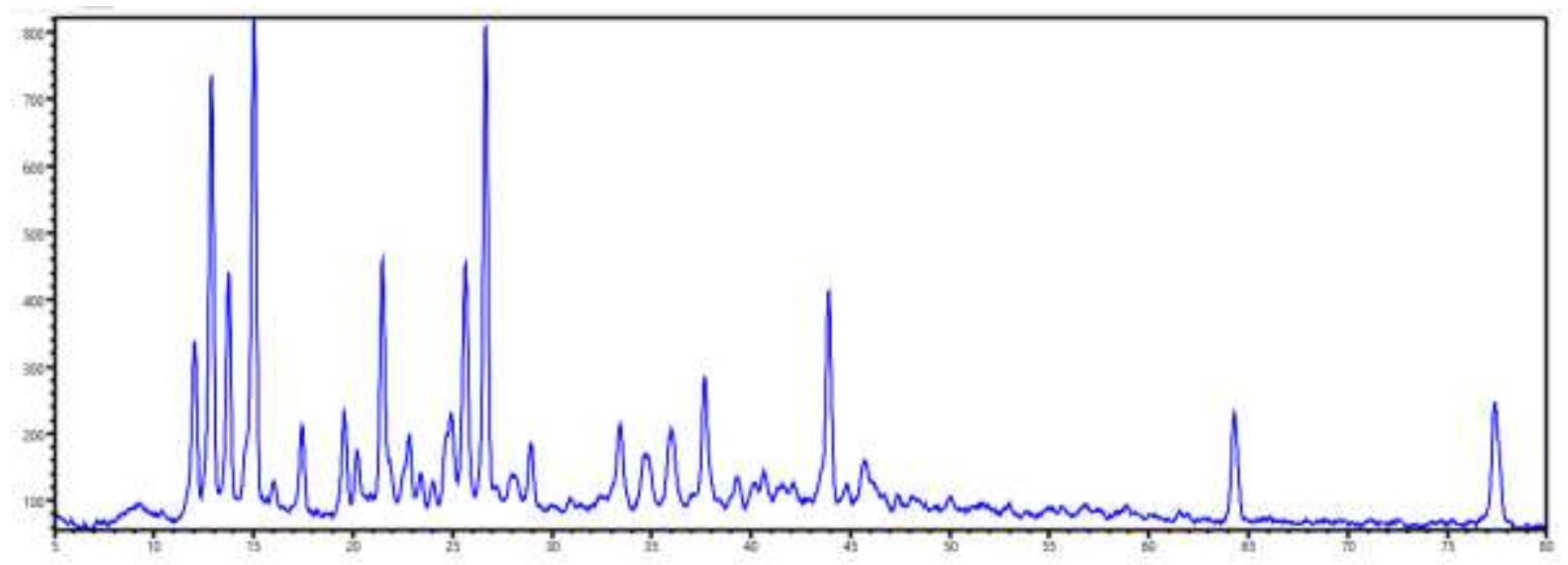

Figure 1: Powder diffraction X-ray spectrum of the monomeric $\left[\mathrm{RuL}^{1} \mathrm{ClH}_{2} \mathrm{O}\right]$ complex

In this context, the Rietveld Refinement technique was applied to achieve precise compatibility between the experimental results and computer processing of the X-ray pattern data of ruthenium(III) based complex 1 as shown in Figure 2; the corresponding PXRD pattern is shown in Figure 1.

The crystallographic data indicate triclinic system of the microcrystalline powder of complex 1 based on the space group value of $\mathrm{P}-1$. The related the crystal lattice are 12.044, 9.946, 7.840 $\AA$ for the dimensions $a, b$ and $c$ respectively (Table 6). The corresponding angles, namely, $\alpha, \beta$ and $\gamma$ have the values of $108.015^{\circ}, 101.354^{\circ}$ and $87.001^{\circ}$ respectively. In the same regard, the cell volume $\left(\AA^{3}\right)$, volume per atom $\left(\AA^{3}\right)$ and the calculated density $\left(\mathrm{g} / \mathrm{cm}^{3}\right)$ are $875.596,14.123$ and 1.976 respectively. Figure 3 shows 
the packing diagram of the unit cell incorporating the number of two molecules of the metallic complex.

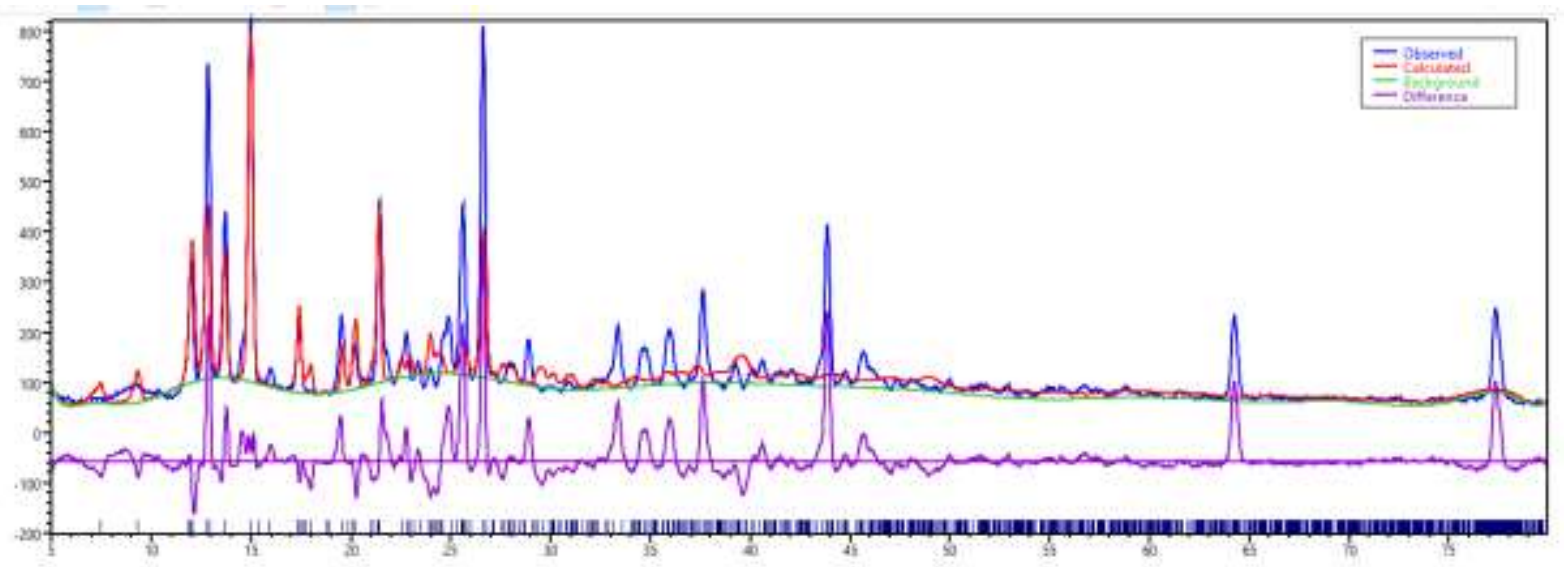

Figure 2: Precise compatibility between the experimental results and computer calculations of the X-ray spectrum of ruthenium(III) based complex 1

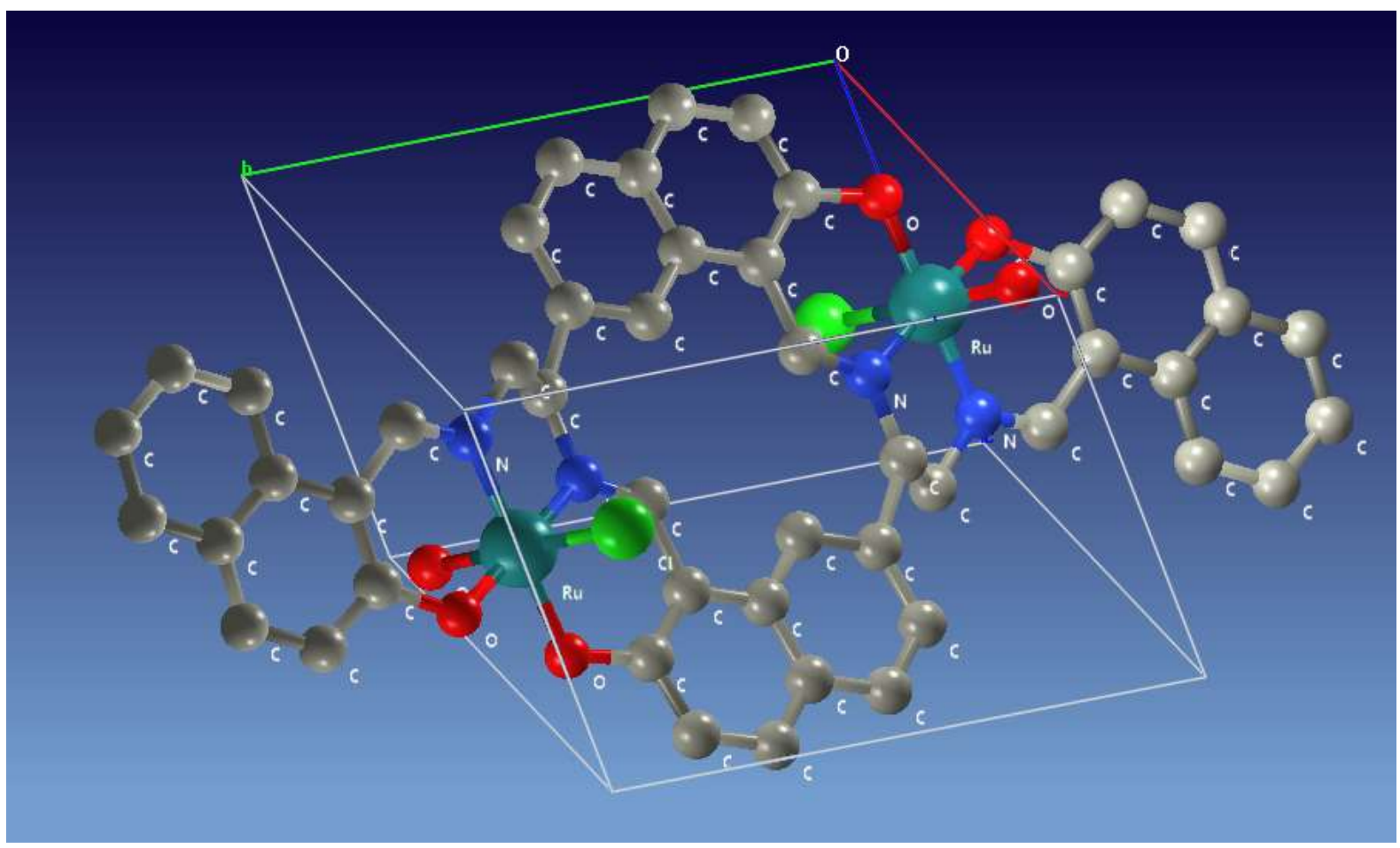

Figure 3: The packing diagram of complex 1

Crystallographic parameters and the relevant structural information such as bond angles and bond distances between the ruthenium(III) ion and donor sites are given in 
Tables 6, 7 and 8 respectively. The approved numbering scheme and the polyhedron octahedral structure are shown in Figures 4 and 5 respectively.

Table 6: Crystallographic results of Ru ${ }^{\text {III }}$-based complex 1

$\begin{array}{ll}\text { Empirical formula } & \mathrm{C}_{24} \mathrm{H}_{2} \mathrm{O} \\ \text { Formula weight } & 520.95 \\ \mathrm{~T}(\mathrm{~K}) & 292 \\ \lambda(\AA) & 1.5406 \\ \text { Crystal system } & \text { Triclinic } \\ \text { Space group } & \mathrm{P}-1 \\ \text { Centro symmetry } & \text { Centric } \\ \text { Space Group Number } & 2 \\ \text { Z } & 2 \\ \text { Multiplicity } & 2 \\ \text { Bravais Lattice } & \mathrm{P} \\ \text { Lattice Symbol } & \mathrm{tP}\end{array}$

\section{Unit cell dimensions:}

$a(\AA), b(\AA), c(\AA)$

$12.044,9.946,7.840$

$\alpha\left({ }^{\circ}\right), \beta\left({ }^{\circ}\right), \gamma\left({ }^{\circ}\right)$

$108.015,101.354,87.001$

Cell volume $\left(\AA^{3}\right)$

875.596

Volume per atom $\left(\AA^{3}\right)$

14.123

Calculated density $\left(\mathrm{g} / \mathrm{cm}^{3}\right)$

1.976

$\theta$ range for data collection $\left(^{\circ}\right)$

$5.000-80.000$

Total reflection

1064

\section{Rietveld results:}

$\mathrm{Rp}$

17.900

Rwp

24.950

R-Bragg

64.661

R-F

19.318

Looking at the optimized octahedron geometry in the numbering adopted scheme Figure 4 it becomes clear that the equatorial plane consists of the four donor sites $\mathrm{O}(19)$, 
$\mathrm{O}(40), \mathrm{N}(20)$ and $\mathrm{N}(39)$. On the other hand, the axial plane is occupied by the aqua oxygen atom $\mathrm{O}(49)$ and the halogeno donor $\mathrm{Cl}(48)$. Designation of the vertical axis locations is based on the fact that the angle between the two axial sites, $\mathrm{O}(49)-\mathrm{Ru}(47)$ $\mathrm{Cl}(48)=179.999^{\circ}$, is the largest compared to the values of the angles between the opposite locations in the equatorial plane (Table 7). In the same context, the bonds distance between $\mathrm{Ru}(47)$ and the two axial sites $\mathrm{O}(49)$ and $\mathrm{Cl}(48)$ are longer compared to the length of bonds between $\mathrm{Ru}(47)$ and the donor sites at the four corners of the basal plane.

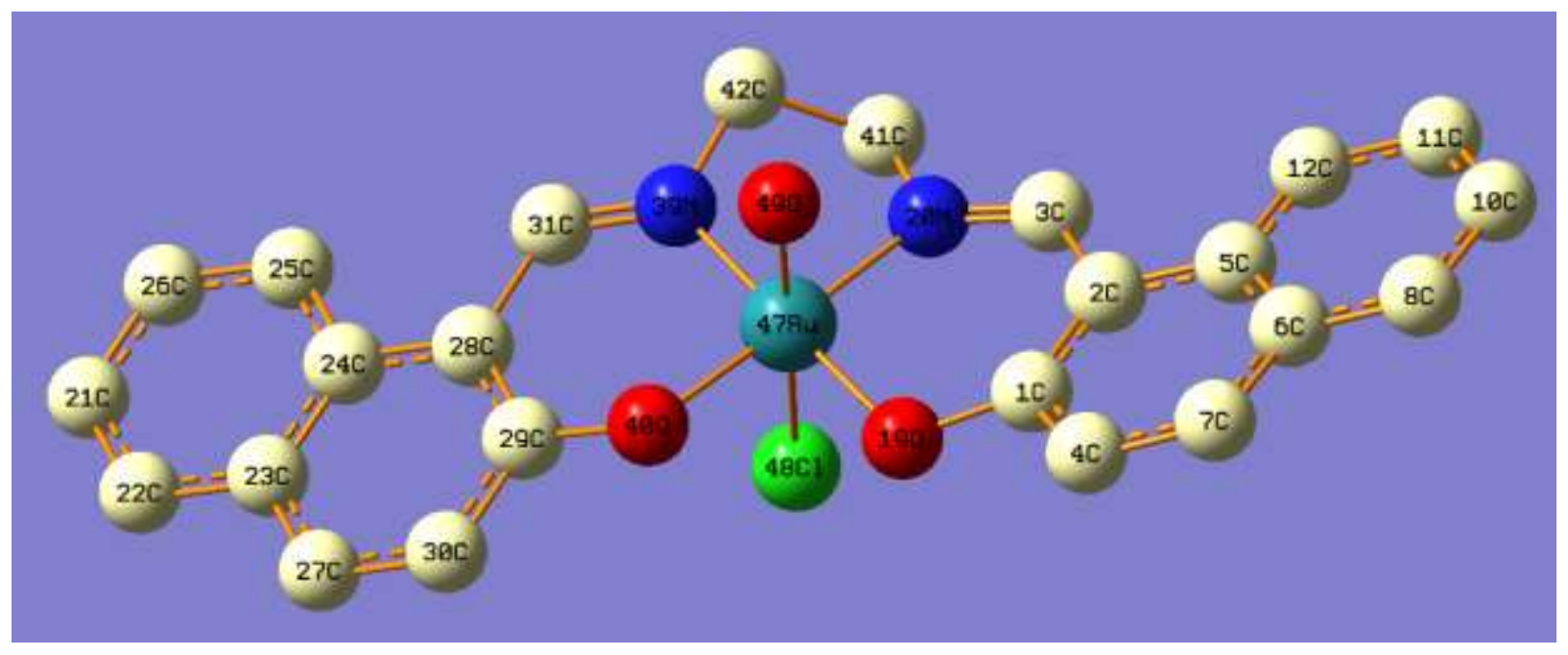

Figure 4: The optimized structure of $\left[\mathrm{RuL}^{1} \mathrm{ClH}_{2} \mathrm{O}\right]$ complex 1

The data in Table 7 indicate that the values of bond angles around the $\mathrm{Ru}(47)$ center almost of $\approx 90^{\circ}$ characteristic to the hybridization of $\mathrm{d}^{2} \mathrm{sp}^{3}$ of the octahedral stereochemistry. For the hexa coordinated metal complexes with the octahedral polyhedron, a question arises about the ideality of this geometry, is it an octahedron or a trigonal prism? Determination the geometrical index " $\tau_{6}$ " gives answer for this question based on the relation $\tau_{6}=\theta / 60$; where $\theta$ is the twist angle between the opposing trigonal faces in the octahedron. In this respect if $\tau_{6}$ equals one this means that the respective geometry is an ideal octahedron while for $\tau_{6}$ equals zero the corresponding structure is a perfect trigonal prism [25]. The calculated value of $\tau_{6}$ is 0.9 and approaches one which indicates that the geometry of the current ruthenium(III) complex is almost a perfect octahedron. 


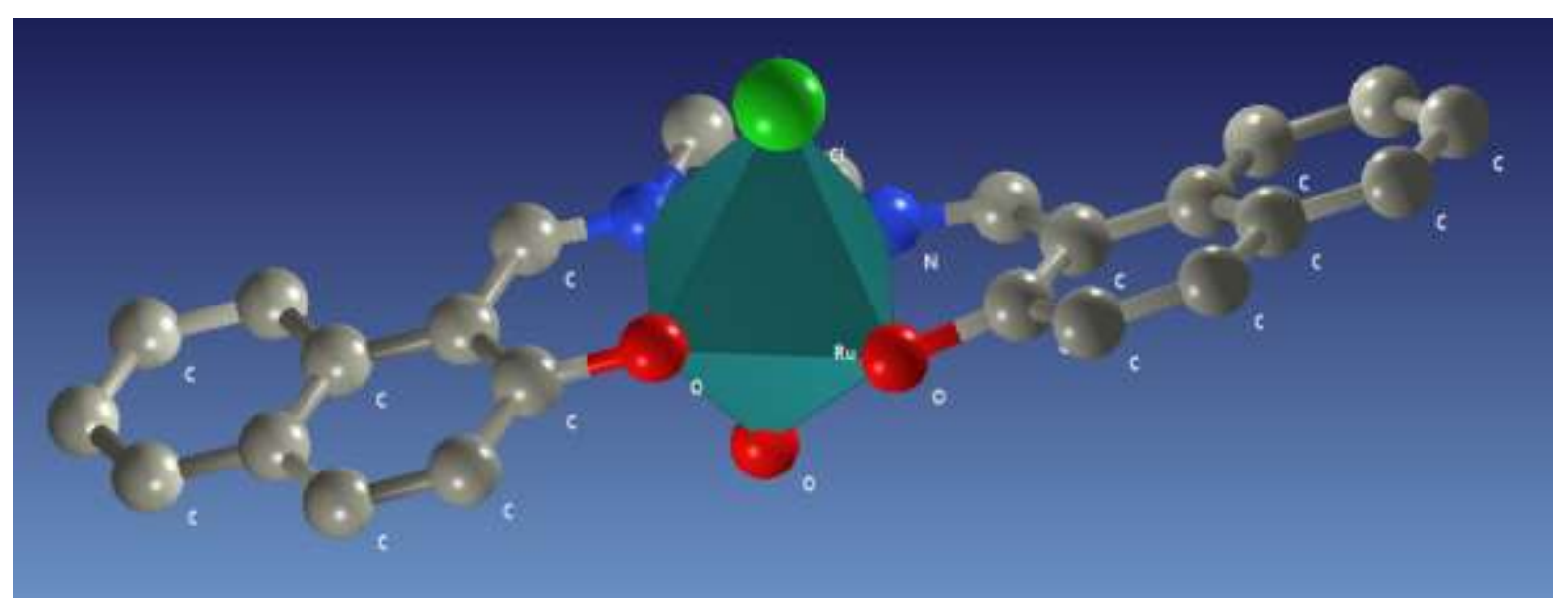

Figure 5: The octaheron plyhedron of $\left[\mathrm{RuL}^{1} \mathrm{ClH}_{2} \mathrm{O}\right]$ complex 1

Table 7: Bond angle ( $\left.{ }^{\ominus}\right)$ around $\mathrm{Ru}(47)$ center for $\left[\mathrm{RuL}^{1} \mathrm{ClH}_{2} \mathrm{O}\right]$ complex 1

\begin{tabular}{ll}
\hline & $(\theta=54) ;$ Octahedral $\tau_{6}=0.9$ \\
\hline O19-Ru47-N20 & 96.560 \\
O19-Ru47-N39 & 178.290 \\
O19-Ru47-O40 & 84.740 \\
O19-Ru47-Cl48 & 89.050 \\
O19-Ru-O49 & 90.990 \\
N20-Ru47-N39 & 81.930 \\
N20-Ru47-O40 & 178.52 \\
N20-Ru47-Cl48 & 90.310 \\
N20-Ru47-O49 & 90.550 \\
N39-Ru47-O40 & 96.770 \\
N39-Ru47-Cl48 & 90.150 \\
N39-Ru47-O49 & 89.840 \\
O40-Ru47-Cl48 & 90.400 \\
C148-Ru47-O49 & 179.999 \\
\hline
\end{tabular}


Table 8: Selected bond distances around $\mathrm{Ru}(47)$ center for $\left[\mathrm{RuL}^{1} \mathrm{ClH}_{2} \mathrm{O}\right]$ complex 1

\begin{tabular}{ll}
\hline Type & Bond distance $(\AA \dot{)})$ \\
\hline $\mathrm{O}(19)-\mathrm{Ru}(47)$ & 1.903 \\
$\mathrm{~N}(20)-\mathrm{Ru}(47)$ & 1.965 \\
$\mathrm{~N}(39)-\mathrm{Ru}(47)$ & 1.949 \\
$\mathrm{O}(40)-\mathrm{Ru}(47)$ & 1.917 \\
$\mathrm{Cl}(48)-\mathrm{Ru}(47)$ & 2.229 \\
$\mathrm{O}(49)-\mathrm{Ru}(47)$ & 1.999 \\
\hline
\end{tabular}

The DFT method comes to provide information about the geometry and hence these results were evaluated by comparison with their peers of experimental crystalline form. The wB97XD/def2-SVPP model chemistry [26] was used for geometry optimizations in the gas phase as implemented in Gaussian 16 suite [27]. The optimized geometrical structures of the studied ruthenium complex, $\left[\mathrm{RuL}^{1} \mathrm{Cl}\left(\mathrm{H}_{2} \mathrm{O}\right)\right]$ is reported in Figures 4 and 5. Interestingly, previous X-ray crystallography studies reported that similar Schiff base metal complexes possess trans and cis isomers, but the trans isomer is more common [28]. Accordingly, we calculated both isomers of $\left[\mathrm{RuL}^{1} \mathrm{Cl}\left(\mathrm{H}_{2} \mathrm{O}\right)\right]$, and in agreement to the above mentioned references, it was found that the trans isomer is more stable than the cis one by $8 \mathrm{kcal} / \mathrm{mol}$. In contrast, the both ruthenium(III) centers of the dimer prefer to adopt cis mode than the trans one by $6 \mathrm{kcal} / \mathrm{mol}$.

For the trans isomer of $\left[\mathrm{RuL}^{1} \mathrm{Cl}\left(\mathrm{H}_{2} \mathrm{O}\right)\right]$, the geometry around the ruthenium center is octahedral with the chloro and $\mathrm{H}_{2} \mathrm{O}$ ligands in a mutually trans orientation, as indicated by the $\mathrm{H}_{2} \mathrm{O}-\mathrm{Ru}-\mathrm{Cl}$ bond angle of $179.999^{\circ}$. The $\mathrm{N}_{2} \mathrm{O}_{2}$ entity of the coordinated Schiff base constitutes the basal plane. The tetradentate $\mathrm{N}_{2} \mathrm{O}_{2}$ coordination of ligand $\mathrm{L}$ to $\mathrm{Ru}(\mathrm{III})$ ion generates three fused chelation rings (two six membered $\mathrm{Ru}-\mathrm{N}-\mathrm{C}-\mathrm{C}-\mathrm{C}-\mathrm{O}$ rings and one five-membered $\mathrm{Ru}-\mathrm{N}-\mathrm{C}-\mathrm{C}-\mathrm{N}$ ring) that are non-coplanar. The dihedral angle between six-membered chelate rings is $3.6^{\circ}$. This model is the most popular of the ruthenium(III)-Schiff base complexes containing $\mathrm{N}_{2} \mathrm{O}_{2}$ donor sites. The bond lengths and bond angles are within the ranges found for other related ruthenium(III) complexes whose exact structures have been determined by X-ray single crystal studies [27]. 
It should be noted here that the results obtained based on DFT calculations agree well with the results of X-ray powder diffraction data processing by Expo 2014, confirming the accuracy of the final structure of the ruthenium(III) complex under study.

\subsection{Catalytic hydrogenation of cyclohexene}

The year 1961 saw the first use of ruthenium complexes for the homogeneous catalytic hydrogenation of the unsaturated bonds with $\mathrm{H}_{2}$ [3f]. Within the framework of the current study the newly synthesized ruthenium(III) Schiff base complexes were tested as catalysts for the reductive hydrogenation of cyclohexene. This seemed particularly interesting, as these complexes have octahedral symmetry instead of the square planar arrangement found for the analogous nickel(II) and palladium(II) naphthaldiimine complexes [2f,4].

The hydrogenation experiments were performed under conditions of hydrogen pressure of 490 Torr, room temperature, catalyst concentrations is $2.6 \times 10^{-3} \mathrm{M}$ while the amount of cyclohexene is $1 \times 10^{-2} \mathrm{M}$. The examined ruthenium(III) chelates exhibited good catalytic conversions of cyclohexene to cyclohexane with yield percentage within the range of 6 to $80 \%$.

To confirm the catalytic potential of the ruthenium(III) complexes under study, blank experiments were carried out in the absence of the catalyst. The results obtained showed that cyclohexane was not formed in these blank experiments, which confirms the catalytic potency of the ruthenium(III) complexes tested. The catalytic potential of studied ruthenium(III) complexes is evaluated using the following relationship:

Yield percentage $=[$ product $/($ reactants + product $)] \times 100$

Influence of catalyst structure, type of catalysis, nature and quantity of co-solvents and solvents were taken into consideration during the evaluation of the catalytic activity.

Early studies reported that the catalytic hydrogenation of alkenes by molecular hydrogen in the presence of metal complexes is strongly influenced by the type and quantity of the solvent and the associated solvent [2e,f,g,h,4]. In this context, DMF proved to be the most widely used solvent in these catalytic reactions and was considered an influential factor in determining the course of many catalytic hydrogenation reactions. [29]. In light of this, DMF was used as a major component in the medium of catalytic reactions during this work. The data in $\mathrm{S} 15$ present the solubility degrees of $\mathrm{H}_{2}$ in the different types and quantities of solvents and co-solvents employed in the present study. 
Cyclohexene is the best choice for measuring the catalytic potential of simple alkenes hydrogenation reactions. This is due to the fact that the product of the hydrogenation process is a single product that is not accompanied by by-products, and this will facilitate the study of the mechanism of this reaction. On the other hand, the use of the corresponding non-cyclic alkene (1-hexene) is not appropriate since the main product of the hydrogenation process is accompanied by the formation of many by-products. This is due to the transfer of the unsaturated bond through the carbon chain of this compound and the formation of a number of structural isomers, which therefore makes it difficult to accurately suggest the mechanism of this reaction.

The results in Table 9 indicate that the present ruthenium(III) diimine complexes catalyze the hydrogenation of cyclohexane by $\mathrm{H}_{2}$ with an efficiency ranging from 6 to $80 \%$ depending on the structure of catalyst and type solvent and co-solvents used. Among the complexes tested (Table 9) the ruthenium(III) complex, $\left[\mathrm{RuL}^{4}\left(\mathrm{H}_{2} \mathrm{O}\right) \mathrm{Cl}\right]$, showed the highest catalytic activity. This variation in catalytic efficiency is due to the difference in the solubility of both $\mathrm{H}_{2}$ and the catalyst in the solvents used. In the same regard, the ruthenium(III) complexes have higher catalytic efficiency than their similar nickel(II) complexes [2f]. In the same regard, the ruthenium(III) diimines exhibit catalytic efficiency comparable with the analogous palladium(II) diimine complexes [4].

The current ruthenium(III) complexes are slightly soluble in ethanol, but completely soluble in DMF. In pure EtOH the activity of the complexes for the catalytic hydrogenation of cyclohexene is reduced (Table 9). These results indicate that the ruthenium(III) complexes act primarily as homogeneous catalysts in DMF in contrast to the analogous nickel(II) and palladium(II) complexes [2f,4]. This result is consistent with the fact that the potency of the ruthenium(III) complexes is significantly decreased in EtOH when compared to the DMF state. This occurs despite the greater solubility of $\mathrm{H}_{2}$ in EtOH compared to DMF as shown in S15. The positive role of EtOH in the mixture with DMF and $\mathrm{H}_{2} \mathrm{O}$ may be explained by acting of $\mathrm{EtOH}$ as a base to promote the formation of an active intermediate, hydrido ruthenium(II) complex, by the following reaction:

$$
\left[\mathrm{Ru}^{\mathrm{III}} \mathrm{LH}_{2} \mathrm{OCl}\right]+\mathrm{H}_{2}+\mathrm{EtOH}(\text { base }) \rightarrow\left[\mathrm{H}-\mathrm{Ru}^{\mathrm{II}} \mathrm{L}\right]+\mathrm{H}_{2} \mathrm{O}+\mathrm{HCl} \text { base }
$$

This behavior of ethanol was previously observed for other ruthenium complexes, e.g. $\left[\mathrm{RuCl}_{2} \mathrm{P}(\mathrm{Ph})_{3}\right][30]$. 
With DMF excluded and under the prevailing practical conditions it is difficult to verify for a specific kind of catalysis. This is due to the always observed partial insolubility of the ruthenium complexes in the other solvents used in the study but the differences in catalytic activity are slight. However, the results in Table 9 demonstrate that the current ruthenium(III) based diimines could catalyze cyclohexene hydrogenation by both the homogeneous and heterogeneous catalysis. An overview of Table 9 shows that for a given ligand, both the type and quantity of the solvent control the catalytic hydrogenation of cyclohexane by $\mathrm{H}_{2}$.

Table 9: Cyclohexane \% produce in presence of ruthenium(III) diimine complexes

\begin{tabular}{lcccc}
\hline Solvent & $\mathrm{RuL}^{1}$ & $\mathrm{RuL}^{2}$ & $\mathrm{RuL}^{3}$ & $\mathrm{RuL}^{4}$ \\
\hline $50 \mathrm{ml} \mathrm{DMF}$ & 60.00 & 55.67 & 58.00 & 60.00 \\
$80 \mathrm{ml} \mathrm{DMF}$ & 68.00 & 62.00 & 65.00 & 67.00 \\
$80 \mathrm{ml} \mathrm{EtOH}$ & 5.80 & 5.00 & 6.00 & 6.00 \\
$\mathrm{DMF} / \mathrm{EtOH}$ & 75.00 & 75.00 & 76.00 & 80.00 \\
$50 \mathrm{ml} / 30 \mathrm{ml}$ & & 76.00 & 70.00 & 74.00 \\
$\mathrm{DMF} / \mathrm{H}_{2} \mathrm{O}$ & 65.00 & & & \\
$50 \mathrm{ml} / 30 \mathrm{ml}$ & & 30.00 & 31.00 & 32.00 \\
$\mathrm{EtOH} / \mathrm{H}_{2} \mathrm{O}$ & 26.10 & & & \\
$50 \mathrm{ml} / 30 \mathrm{ml}$ & & & & \\
\hline
\end{tabular}

It is observed that the difference in the structures of the newly synthesized ruthenium(III) diimines is attributed to the numbers of carbon atoms of the alkyl bridge of the central chelated ring. The data in Table 6 reveal that the structural variation of the current ruthenium(III) complexes does not affect the catalytic efficiency of these ruthenium(III) based complexes. This perception is consistent with the fact that the donor sites $\left(\mathrm{N}_{2} \mathrm{O}_{2}\right)$ of Schiff base are in the xy plane and the constituents of the alkyl bridge are too far off this plane. In this case, the alkyl bridge of whatever length does not cause any steric effect that prevents the metal ion from bonding to either $\mathrm{H}_{2}$ or cyclohexene during the catalytic cycle. Moreover, for all ruthenium(III) complexes the good leaving groups $\mathrm{H}_{2} \mathrm{O}$ and $\mathrm{Cl}^{-}$occupy the axial plane which participates in the catalysis process (Scheme II). 


\section{Suggested mechanism}

Hydrogenation of cyclohexene by $\mathrm{H}_{2}$ could proceed via electrons flow from the HOMO of the unsaturated double bond of cyclohexene ( $\pi$ - orbital) to the LUMO of the hydrogen molecule $\left(\sigma^{*}\right)$. Or the electrons flow can come from the $\mathrm{HOMO}$ of $\mathrm{H}_{2}(\sigma)$ to the LUMO for the unsaturated double bond of cyclohexene $\left(\pi^{*}-\right.$ orbital). For the first or second path to occur, there must be a complete overlap between the interacting orbits, and this will not be achieved on the ground. Accordingly, these symmetry limitations can be overcome with the use of an appropriate catalyst and this is the role of the present ruthenium (III) complexes. In this context, the catalysis of this symmetric-blocked reaction could be accomplished by activation of either $\mathrm{H}_{2}$ or cyclohexene as shown by pathways (a) and (b).

$\mathrm{Cat}+\mathrm{H}_{2} \stackrel{\mathrm{K}_{1}}{\rightleftharpoons} \mathrm{CatH}+\mathrm{S} \stackrel{\mathrm{k}^{\prime}}{\longrightarrow}$ Cat + alkane
$\mathrm{Cat}+\mathrm{S} \stackrel{\mathrm{K}_{2}}{\rightleftharpoons} \mathrm{CatS}+\mathrm{H}_{2} \stackrel{\mathrm{k}^{\prime \prime}}{\longrightarrow} \mathrm{Cat}+$ alkane

To distinguish between these two possible pathways, the following practical procedure was implemented: In the absence of ruthenium(III) complex, the reaction vessel was saturated with hydrogen gas, but the reaction between hydrogen and cyclohexane did not occur. In the same regard, repeating the same experiment in the presence of the ruthenium(III) complexes in question and the absence of olefin resulted in a remarkable decrease in the hydrogen gas pressure by an amount proportional to the amount of the catalyst in the reaction vessel. In light of this practical procedure, we can assume that the first path (a) is the dominant pathway and, therefore, the catalytic course of this reaction can be visualized and discussed as follows.

Since the examined complexes $\left[\mathrm{RuL}^{\mathrm{n}} \mathrm{ClH}_{2} \mathrm{O}\right] ; \mathrm{n}=1-4$, are hexa coordinate and thus have no free coordinated sites for binding the reactants to perform the catalytic process. In this case, one of the axial good leaving ligands $\left(\mathrm{Cl}\right.$ or $\left.\mathrm{H}_{2} \mathrm{O}\right)$ must be dissociate to provide a vacant coordination site for binding either $\mathrm{H}_{2}$ or cyclohexene to initiate the hydrogenation process. Accordingly, $\left[\mathrm{RuL}^{\mathrm{n}} \mathrm{ClH}_{2} \mathrm{O}\right]$ is a precatalyst and the actual active catalyst is generated in the reaction medium (in situ). According to the polarization theory, $\mathrm{H}_{2} \mathrm{O}$ is less polarized than chloro ligand, and therefore less bound to 
ruthenium(III) center. Thus the spark of this catalytic reaction is the substitution reaction between $\mathrm{H}_{2} \mathrm{O}$ and $\mathrm{H}_{2}$ to produce the intermediate $\left[\mathrm{H}_{2} \mathrm{RuL}{ }^{\mathrm{n}} \mathrm{Cl}\right]$ in a fast step.

Coordination of the ruthenium(III) center with molecular hydrogen induces $\mathrm{H}_{2}$ activation resulting in a heterogeneous cleavage of the $\mathrm{H}-\mathrm{H}$ sigma bond with the concomitant formation of mono hydrido species, $\left[\mathrm{H}-\mathrm{RuL}^{\mathrm{n}}\right]$, followed by separation of the $\mathrm{HCl}$ molecule. It is clear that the release of the chloride ion in the form of hydrochloric acid will balance the official charge on the ruthenium(III) ion according to the viewpoint of the principle of electroneutrality [31]. This displacement of the chloro ligand from the coordination sphere provides a free coordination site for binding of cyclohexene to ruthenium(III) center to complete the catalytic hydrogenation cycle. The cyclohexene molecule can then coordinate to the hydrido $-\mathrm{Ru}^{\mathrm{III}}$ intermediate, $\left[\mathrm{H}-\mathrm{RuL}^{\mathrm{n}}\right]$, to give an olefin - hydrido - ruthenium(III) adduct, [H-RuL ${ }^{\mathrm{n}}$-olefin]. The resulting adduct will be rearranged to $\sigma$ - alkyl intermediate by insertion of the olefin molecule into the metal hydride bond.

It is generally assumed that the insertion occurs by means of a synergistic reaction pathway, via a more or less polar circular transmission state involving fracture and formation of bonds simultaneously [32]. Electrophilic attack by a proton on the carbon atom bonded to the metal yields the saturated product and regenerates the catalyst in its free active form. The catalytic cycle proposed for the homogeneous hydrogenation of cyclohexene using the chosen complex, $\left[\mathrm{RuL}^{n} \mathrm{ClH}_{2} \mathrm{O}\right]$, may therefore be represented as shown in scheme II. 


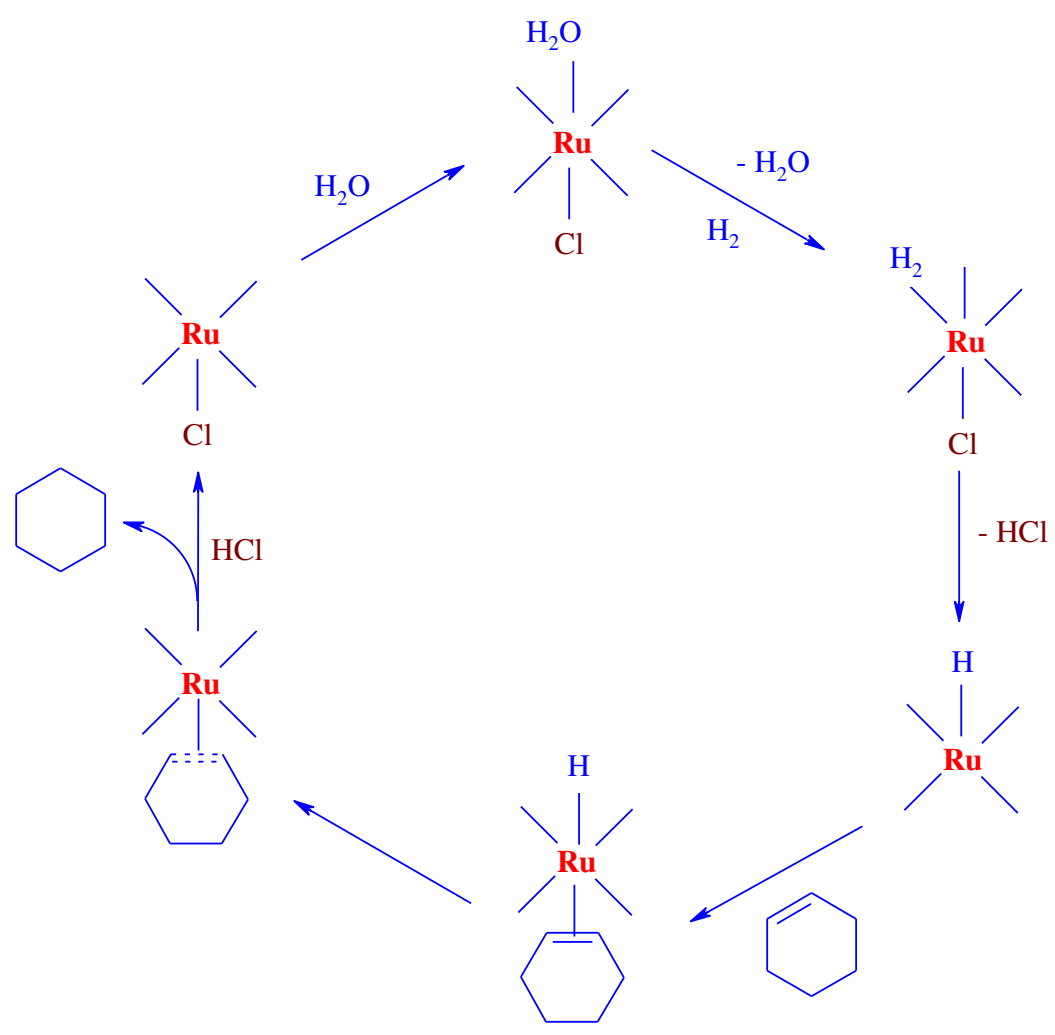

Scheme II: Catalytic cycle for the hydrogenation of cyclohexene by using $\left[\mathrm{RuL}^{\mathrm{n}} \mathrm{ClH}_{2} \mathrm{O}\right]$ 


\section{Conclusion}

In this contribution, four diimine ligands were synthesized via Schiff condensation between 2-OH-1-naphthaldehyde and a number of aliphatic diamines with carbon chain ranging from two to six. The pure isolated ligands interacted with $\mathrm{RuCl}_{3} 3 \mathrm{H}_{2} \mathrm{O}$ to afford a series of metal chelates. Several physicochemical and spectroscopic techniques were employed to characterize the structural formulae of the prepared compounds. Octahedral structure was assigned for the newly synthesized ruthenium(III) diimine based complexes. Confirmation of the assigned structural formula of complex 1 was achieved by PXRD and DFT calculations. Catalytic hydrogenation of cyclohexene by $\mathrm{H}_{2}$ in presence of the $\mathrm{Ru}^{\mathrm{III}}$-based complexes in question was studied. The catalytic investigations included effect of catalyst structure, type of catalysis and nature and amount of solvent and cosolvent on the yield of the catalytic hydrogenation processes. The results in Table 9 show that there is a relationship between both the type and quantity of the solvent used and the values of yield percentage of cyclohexane. Moreover, the results obtained allowed establishing that the catalytic hydrogenation reaction takes place through $\mathrm{H}_{2}$ activation pathway. As well the catalytic investigations of the current hydrogenation process allowed us to suggest a catalytic cycle.

\section{Acknowledgment}

Taif University Researchers Supporting Project number (TURSP-2020/14), Taif University, Taif, Saudi Arabia

\section{CONFLICT OF INTEREST}

The authors declare that there are no conflicts of interest regarding the publication of this research paper 


\section{References}

[1] a) B. Chen, U. Dingerdissen, J. G. E. Krauter, H. G. J. Lansink Rotgerink, K. Möbus, D. J. Ostgard, P. Panster, T. H. Riermeier, S. Seebald, T. Tacke, H. Trauthwein, Appl. Catal. A, 280 (2005) 17; b) S. Lavielle, S. Bory, B. Moreau, M. J. Luche, A. Marquet, J. Am. Chem. Soc. 100 (1978) 1558; c) B. M. Goortani, A. Gaurav, A. Deshpande, F. T. T. Ng, G. L. Rempel, Ind. Eng. Chem. Res., 54, (2015) 3570; d) G. R. List, J. W. King, Hydrogenation of Fats and Oils: Theory and Practice, AOCS Press, $2^{\text {nd }}$ Ed., (2015); e) L. A. Saudan, Acc. Chem. Res., 40 (2007) 1309

[2] a) J. Barbier, E. Lamy-Pitara, P. Marecot, J. P. Boitiaux, J. P. Cosyns, F. Verna, Adv. Catal. 37 (1990) 279; b) L. V. Nosova, V. I. Zikovskii, Y. A. Ryndin, React. Kinet. Catal. Lett. 53 (1994) 131; c) L.-M. Tang, M.-Y. Huang, Y.-Y. Jiang, Macromolecules 15 (1994) 527; d) V. M. Frolov, Platinum Metals Rev. 40 (1996) 8, e) A. M. Ramadan, Transition Met. Chem., 21 (1996) 536; f) A. M. Ramadan, W. Sawodny, H. Y. F. ElBaradie, M. Gaber, Transition Met. Chem., 22 (1997) 211; g) R. Ohl, Dissertation, Ulm University, Germany, (1990); h) R. Ohl, M. Sc. Thesis, Ulm University Germany, 1988

[3] a) F. P. da Silva, J. L. Fiorio, L. M. Rossi, ACS Omega, 2 (2017) 6014; b) D. Schleyer, H. G. Niessen, J. Bargon, New. J. Chem., (2001) 423; c) J. Navarro, M. Sagi, E. Sola, F. J. Lahoz, I. T. Dobrinovitch, A. Katho, F. Joo and L. A. Oro, Adv. Synth. Catal., 345 (2003) 280; d) F. Nerozzi, Platin. Met. Rev., 56 (2012) 236; e) M. Irfan, T. N. Glasnov, C. O. Kappe, Chem.Sus.Chem., 4 (2011) 300; f) J. F. Harrod, S. Ciccone, J. Halpern, Can. J. Chem., 39 (1961) 1372

[4] M. M. Ibrahim, A. M. Fathy, S. A. Al-Harbi, S. A. Sallam, S. Al-Juaid, A. M. Ramadan, J. Organometallic Chem., 939 (2021) 121764; and references their in.

[5] B. R. James, Homogenous Hydrogenation, John Wiley \& Sons, New York, 1973

[6] a) D. Evans, J. A. Osborn, F. H. Jardine, G. Wilkinson, Nature, 208 (1965) 1203; b) T. Naota, H. Takaya, S. Murahashi, Chem.Rev. 98 (1998) 2599; c) C. Pranckevicius, L. Fan, D. W. Stephan, J. Am. Chem. Soc., 137 (2015) 5582; d) D. Schleicher, H. Leopold, H. Borrmann, T. Strassner, Inorg. Chem. 56 (2017) 7217; e) D. Schleicher, H. Leopold, T. Strassner, J. Organomet. Chem. 829 (2017) 101; f) J. P. Lee, Z. Ke, M. A. Ramírez, T. B. Gunnoe, T. R. Cundari, P. D. Boyle, J. L. Petersen, J. Organometallics, 28 (2009) 1758-1775; g) C. L. Lund, M. J. Sgro, R. Cariou, D. W. Stephan, J. Organometallics, 31 (2012) 802 
[7] a) B. Bagh, A. M. McKinty, A. J. Lough, D. W. Stephan, Dalton Trans. 44 (2015) 2712; b) H. M. Lee, D. C. Smith, Z. He, E.D. Stevens, C. S. Yi, S. P. Nolan, J. Organometallics, 20 (2001) 794

[8] G. Henrich-Olive, S. Olive, J. Mol. Catal., 1 (1976) 121

[9] M. M. Taquikhan, S. B. Halligudi, S. Shukhlaand, Z. A. Shaikh, J. Mol. Cat., 57 (1990) 301

[10] M. R. Fox, P. L. Orioli, E. C. Lingafelter and L. Sacconi, Act Cryst., 17, (1964) 1159

[11] P. W. Selwood, Magento Chemistry, Interscience Publisher, Inc., New York, 1956

[12] W.J. Geary, Coord. Chem. Rev., 7: (1971) 81

[13] F. M. Ashmawy, R. M. Issa, S. A. Amer, C. A. McAuliffe, R.V. Parish, J. Chem. Soc., Dalton Trans., (1986) 421; C. A. McAuliffe, R.V. Parish, S. M. Abu-El-Wafa, R. M. Issa, Inorg Chim Acta, 115 (1986) 91

[14] K. Nakamoto, Infrared and Raman Spectra of Inorganic and Coordination compounds, Wiley, New York, 1986

[15] K. Yamanoouchi, S. Yamada, Inorg Chim Acta, 12 (1975) 9

[16] C. Daul and A. Goursot, Inorg. Chem., 24 (1985) 3554

[17] A. B. P. Lever, Inorganic Electronic Spectroscopy, Elsevier, Amsterdam, 1968

[18] C. J. Ballhausen, Introduction to Ligand Field Theory, McGraw-Hill, New York, 1962

[29] Y. Tanabe and S. Sugano, J. Phys. Soc. Jpn., 9 (1954), 766

[20] C. Preti, G. Tosi and P. Zannini, J. Inorg. Nucl. Chem., 41 (1979) 485

[21] H. G. Gray, C. J. Ballhausen, J. Am. Chem. Soc., 85 (1963) 260; J. Lewis, B. N. Figgis, Prog. Inorg. Chem., 6 (1964) 105; B. N. Figgis, Trans. Faraday Sorr., 57 (1961) 198

[22] F. A. El-Saied, R. M. El-Bahnasawy, M. Abdel-Azeem, and A. K. El-Sawaf, Polyhedron, vol. 13, 11, (1994) 1781

[23] P. A. Chaloner, Theortical Inorganic Chemistry, McGraw Hill Inc., New York, (1969)

[24] K. A. Alibrahim, F. A. Al-Saif, M. T. Alghamdi, M. S. El-Shahawi, Y. M. Moustafa, M. S. Refat, RSC Adv., 8 (2018) 22515; S. Chandra, Synth. React. Inorg., Met.-Org., Nano-Met. Chem., , 22 (10) (1992) 1565; C. Thirupataiah, D. P. Chary, M. Ravinder, S. 
Srihari, Oriental Journal of Chemistry, Vol., 24 (3) (2008) 859; N. Thilagavathi, C. Jayabalakrishnan, Cent. Eur. J. Chem., 8 (4) (2010) 842; V. K. Sharma, S. Srivastava, A. Srivastava, Bioinorganic Chemistry and Applications, 2007(4) (2007) 68374; A. M. Ramadan, R. M. Issa, Transition Met. Chem., 22 (1997) 529

[25] A. Avdeef, J. P. Fackler Jr., Inorg. Chem., 14 (1975) 2002; D. L. Kepert, Inorg. Chem., 11 (1972) 1561

[26] J.-D. Chai, M. Head-Gordon, J. Chem. Phys., 128 (2008) 084106

[27] M. Frisch, et al., Gaussian 16 Rev. B. 01, Wallingford, CT. 2016

[28] a) L. H. Tang, F. Wu, H. Lin, A.-Q. Jia, Q.-F. Zhang, Inorg. Chim. Acta, 477 (2018) 212; b) J. Ji, X. Chen, C-J Wang, A-Q Jia, J. Coord. Chem., 72 (3) (2019) 480; c) Y. Li, Q. Ma, H.-T. Shi, Q. Chen, Q.-F. Zhang, Z. Naturforsch., 66b (2011), 324; d) K. Matsumoto, B. Saito, T. Katsuki, Chem. Commun., (2007) 3619-3627.

[29] a) F. R. Hartley, J. A. Davis, Rev. Inorg. Chem., 4, (1982) 27; b) A. Bose and C. R. Saha, J. Mol. Catal., 49, (1982) 271

[30] P. S. Hallman, D. Evans, J. A. Osborn, G. Wilkinson, Chem. Comm., (1967) 305; P. S. Hallman, B. R. McGarvey, G. Wilkinson, J. Chem. Soc., (A) (1968) 3143

[31] J. E. Huheey, Inorganic Chemistry Principles of Structure and Reactivity, $3^{\text {rd }}$ Ed., London, (1983)

[32] G. H. Olive, S. Olive, Coordination and Catalysis, Monographs in Modern Chemistry, Volume 9, Verlag Chemie, (1977) 
Figures

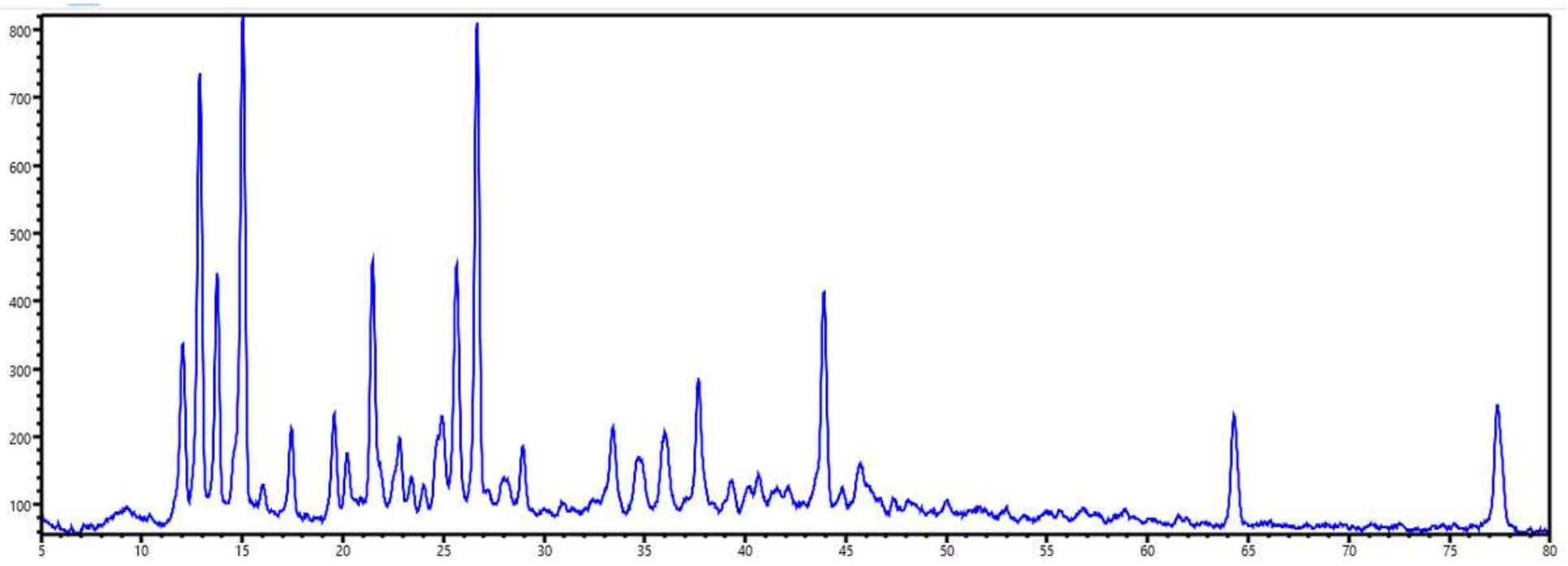

Figure 1

Powder diffraction X-ray spectrum of the monomeric [RuL1ClH2O] complex

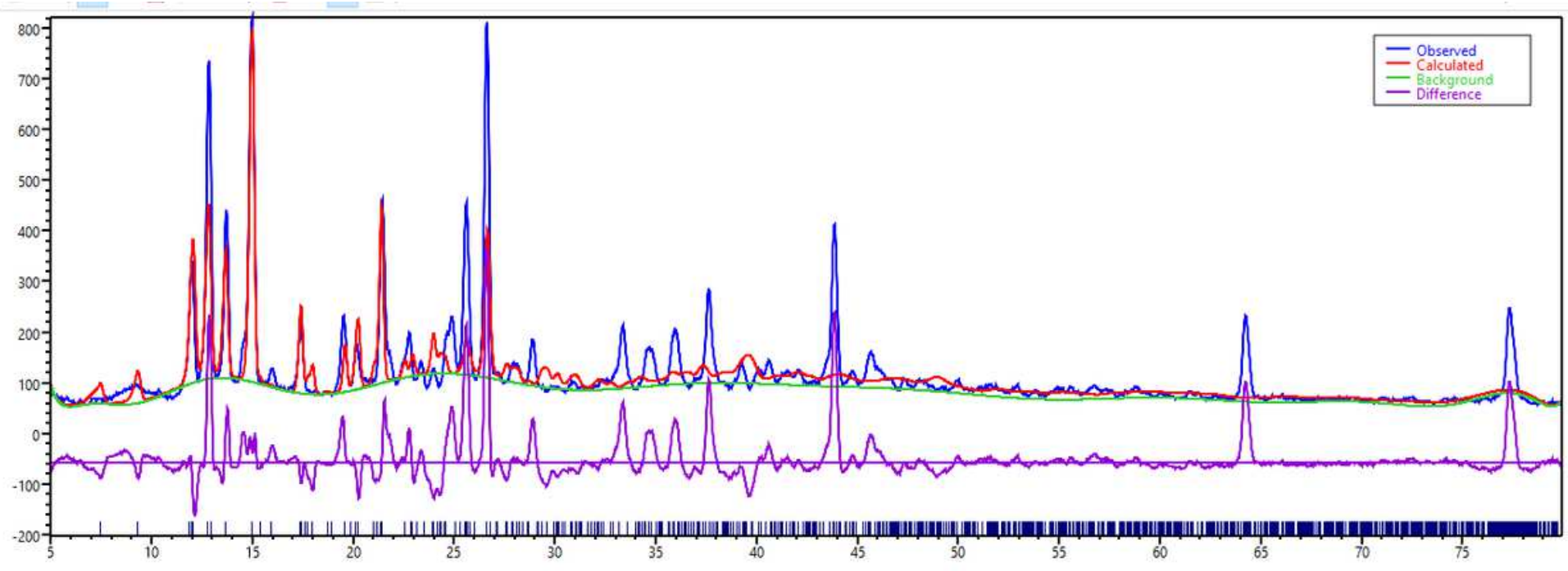

Figure 2

Precise compatibility between the experimental results and computer calculations of the X-ray spectrum of ruthenium(III) based complex 1 


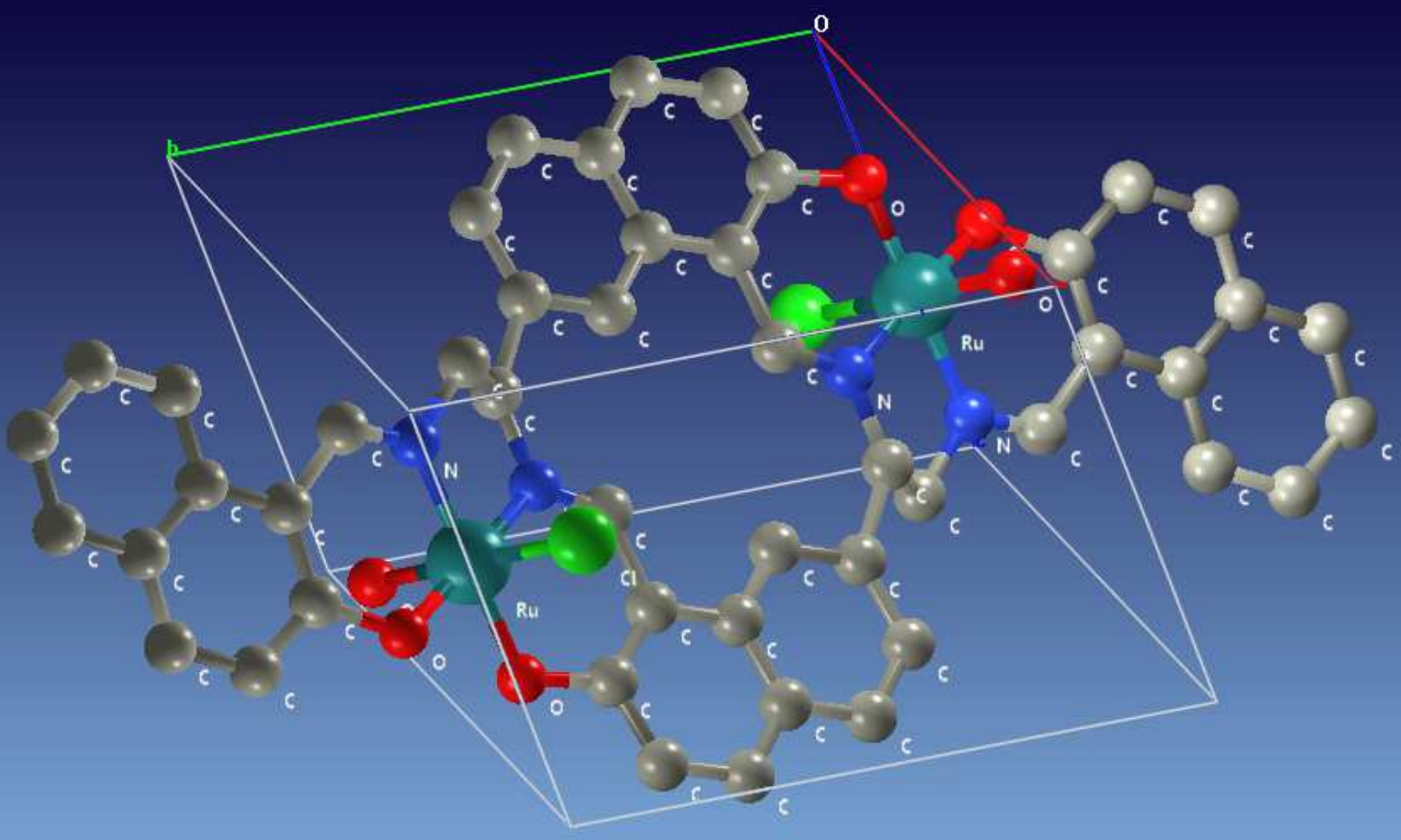

Figure 3

The packing diagram of complex 1

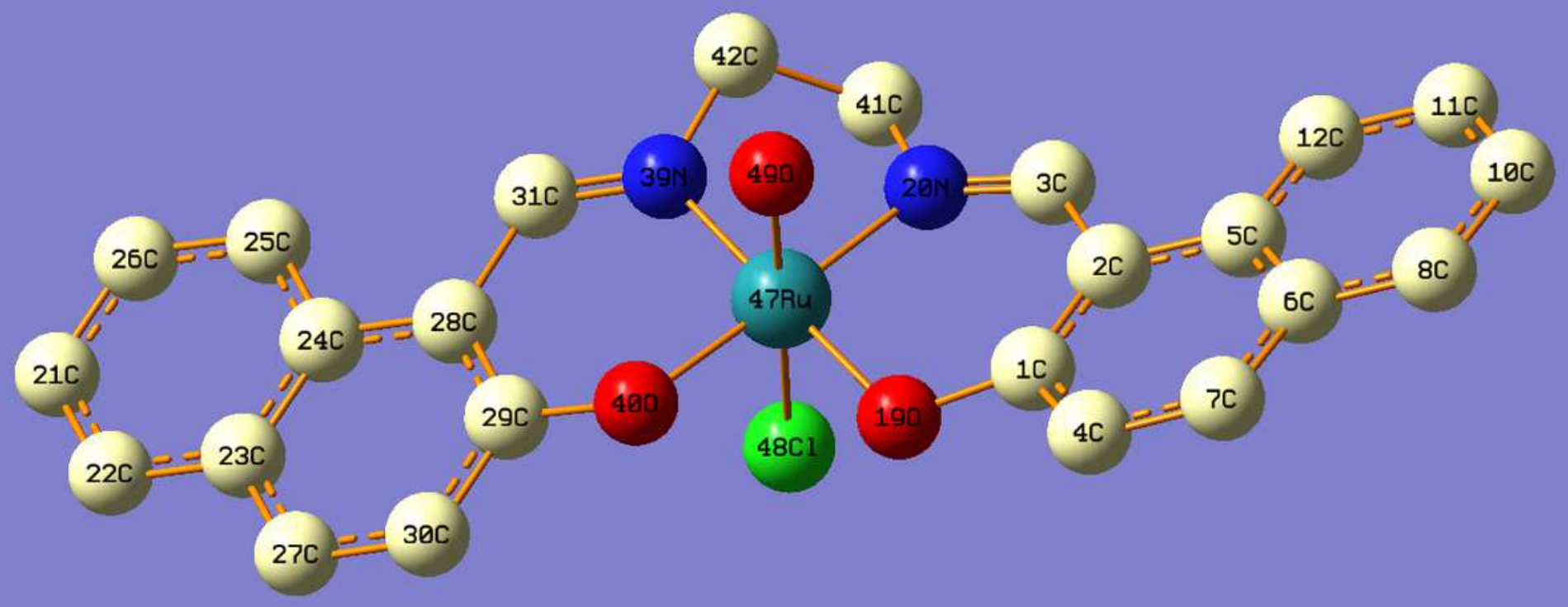

Figure 4

The optimized structure of [RuL1ClH2O] complex 1 


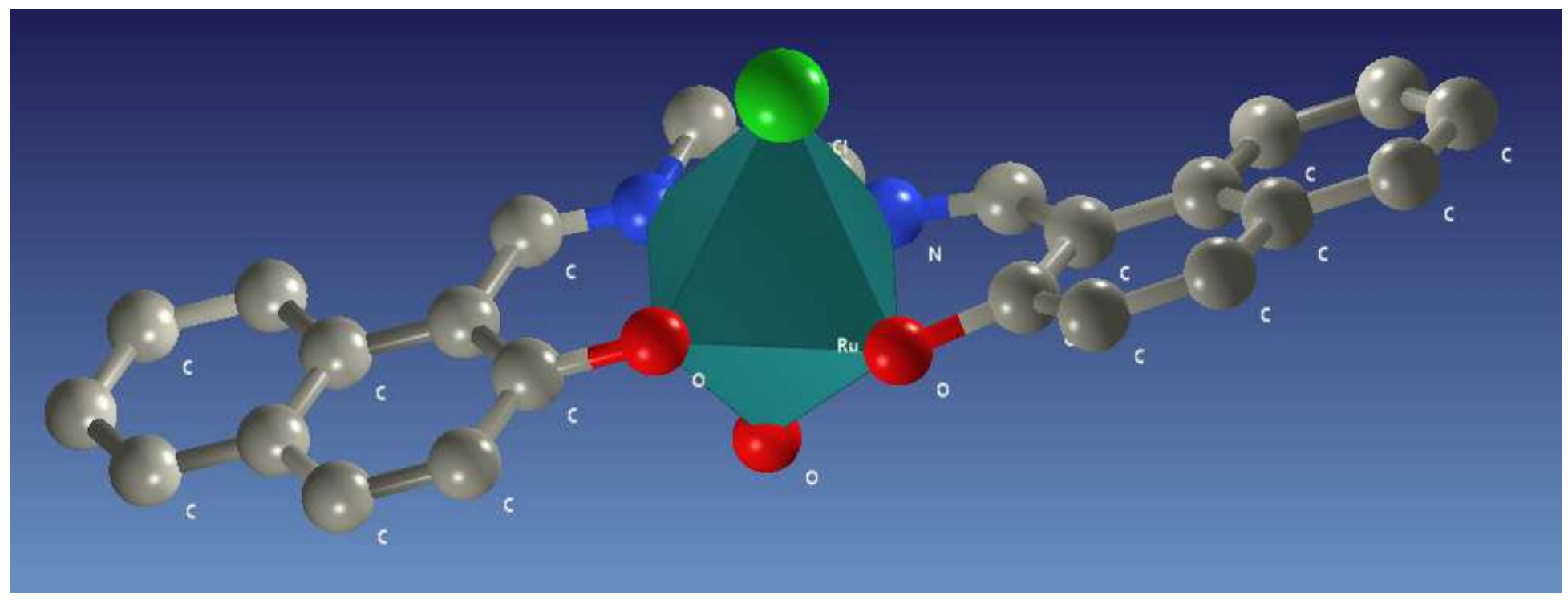

Figure 5

The octaheron plyhedron of [RuL1ClH2O] complex 1

\section{Supplementary Files}

This is a list of supplementary files associated with this preprint. Click to download.

- Scheme01.png

- Scheme02.png

- Supplementarymaterials.doc 